\title{
Acumulação primitiva socialista na China: uma visão alternativa das anomalias do "capitalismo" chinês
}

Primitive socialist accumulation in China: an alternative view on the anomalies of chinese "capitalism"

\section{səm-kee cheng*}

DOI: https://doi.org/10.4322/principios.2675-6609.2021.162.012

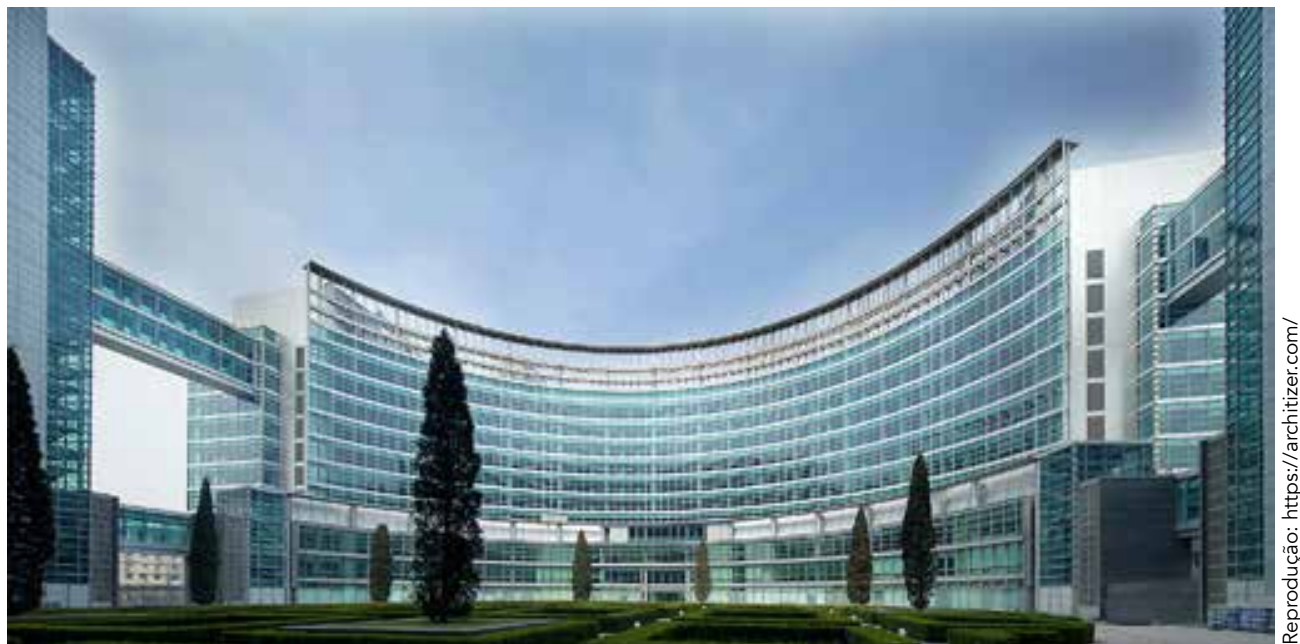

Fase II do projeto arquitetônico da sede do banco chinês ICBC no novo distrito financeiro de Pequim

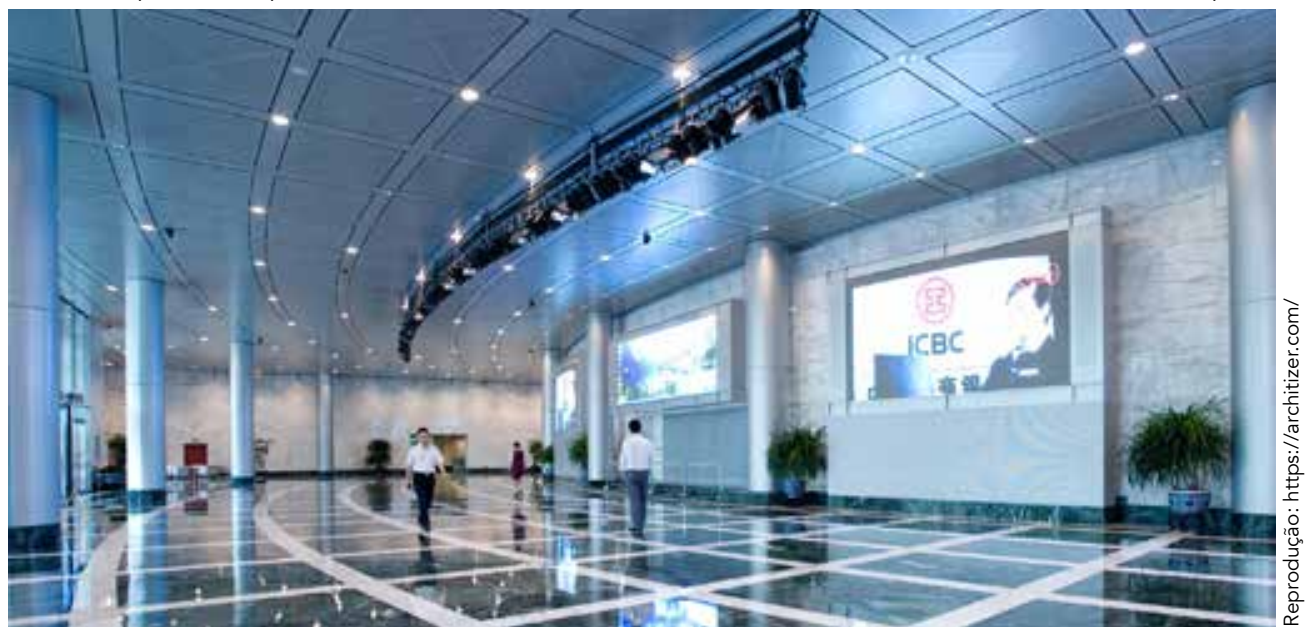




\section{RESUMO}

O sistema econômico chinês ainda não foi adequadamente explicado por nenhum modelo. As indústrias de exportação da China foram de início vistas como uma fonte de mão de obra barata, mas sua economia emergiu como um competidor sério no capitalismo avançado. No entanto, depois de décadas de reformas de mercado, o setor estatal da China, em vez de desaparecer ou ser marginalizado, tornou-se líder em setores estratégicos e motor do crescimento do país, focado em investimento. Cientistas políticos e economistas heterodoxos há muito tempo argumentam que a China é, na melhor das hipóteses, uma variante do capitalismo global. Este artigo discute teorias heterodoxas que concebem a China como parte do capitalismo global ou a veem como uma variedade do capitalismo. Ele então examina as anomalias do "capitalismo" chinês e sugere que a acumulação primitiva socialista — operando em conflito com a acumulação capitalista — oferece um quadro teórico mais apropriado para se estudar o desenvolvimento da China.

Palavras-chave: Capitalismo chinês. Acumulação primitiva socialista. Preobrazhensky. Empresas estatais. Corporativismo.

\section{ABSTRACT}

China's economic system has yet to be adequately explained by any models. China's export-led industries were initially viewed as a source of cheap labor but its economy has now emerged as a serious competitor to advanced capitalism. However, after decades of market reform, China's state sector, rather than disappearing or being marginalized, has become a leader in strategic sectors and the driver of its investment-led growth. Heterodox political scientists and economists have long argued that China is at best a variant within global capitalism. This paper discusses heterodox theories that position China as part of global capitalism or regard it as a variety of capitalism. It then examines the anomalies of Chinese "capitalism" and suggests that primitive socialist accumulation - operating in conflict with capitalist accumulation offers a more appropriate theoretical framework for studying China's development.

Keywords: Chinese capitalism. Primitive socialist accumulation. Preobrazhensky. State-owned enterprises. Corporatism. 


\section{INTRODUCÃO}

Diz-se que a reforma de mercado na China, em 1978, marcou a transição de uma economia planificada para uma economia de mercado. O sucesso da China é atribuído à adoção do capitalismo sob a supervisão do Partido Comunista. A economia chinesa hoje é certamente muito diferente da que havia na era pré-reforma de mercado; ainda assim, as indústrias estratégicas, que Lênin chamou de "alto comando da economia", ainda são estatais e tiveram um papel muito importante no desenvolvimento econômico chinês (HEILMANN; MELTON, 20I3; XU, 20I7). Enquanto muitos economistas tradicionais e governos ocidentais se tornaram céticos a respeito da aceitação da economia de mercado por parte da China, algo exemplificado na contínua recusa dos Estados Unidos, União Europeia e Japão de concederem ao país o status de economia de mercado (ZALAN, 20I6), a maior parte das organizações políticas e acadêmicos de esquerda do Ocidente não hesita em atribuir o crescimento econômico da China à sua incorporação ao sistema capitalista global e em criticar essa associação. Alguns veem a China como uma potência imperialista emergente. No entanto, o governo chinês tem buscado um crescimento impulsionado por investimentos e obteve uma melhora considerável no padrão de vida local, o que cria um forte contraste com a tendência geral de austeridade. Além disso, o comércio exterior da China e seu investimento em países em desenvolvimento, especialmente por meio de empresas e bancos estatais, melhorou os termos de troca com seus parceiros, especialmente durante a recessão global de 2008. Tanto a "Nova Rota da Seda" ("Belt and Road Iniciative") comandada pela China quanto o Banco Asiático de Investimento em Infraestrutura buscam tratar de falhas no desenvolvimento de infraestrutura no mundo desenvolvido e em desenvolvimento.

Apesar das diferenças claras com as doutrinas neoliberais, alguns teóricos heterodoxos ainda veem a China como um Estado neoliberal. Eles argumentam que, ao fazer o capitalismo funcionar por meio de intervenção estatal, a China está apoiando a hegemonia estadunidense e é cúmplice do capitalismo global (PANITCH; GINDIN, 20I2; HARVEY, 2007; HART-LANDSBERG; BURKETT, 2005). Alguns consideram que tais diferenças são características do capitalismo chinês, uma variedade de capitalismo que teria o potencial de rivalizar com o capitalismo anglo-americano (MCNALLY, 20I2; TEN BRINK, 20I4). Embora esses teóricos discordem quanto aos possíveis resultados, veem o desenvolvimento capitalista da China como a principal razão tanto para a sua aderência ao resto do capitalismo mundial como para suas diferenças em relação a ele.

Contudo, as anomalias na política econômica chinesa não só não desaparecem como se tornam mais proeminentes, especialmente durante a recessão global. Lo (20I6b) acompanha a trajetória mutante da política econômica chinesa durante os anos da reforma de mercado e mostra que ela tem um caráter duplo: submissa e também resistente às dinâmicas sistemáticas do capitalismo global. Lo (20I6a) desco- 


\section{O setor estatal chinês não foi}

marginalizado; sua influência na

economia foi fortalecida e sua

competitividade internacional

aumentou. A esmagadora

maioria das principais

corporações chinesas é estatal

bre que o modelo econômico chinês tem sido, em linhas gerais, antitético ao modelo neoliberal, embora demonstrando certa orientação neoliberal desde 2008, com uma proporção cada vez maior de investimento em atividades não produtivas. $\mathrm{O}$ setor estatal chinês não foi marginalizado; sua influência na economia foi fortalecida e sua competitividade internacional aumentou. A esmagadora maioria das principais corporações chinesas é estatal. Na lista da Fortune Global 500 de 20I8, III firmas chinesas estavam presentes, e, no top Ioo, 22 eram chinesas e apenas uma (Huawei, em $72^{\circ}$ ), privada (BOFIT, 20I8). Estatais também são responsáveis pela maior parte do investimento direto da China no exterior; elas responderam por 53,6\% das ações de investimento direto da China no estrangeiro em 20I4 (MOFCOM, 2015). A produtividade dessas empresas também aumentou exponencialmente. De entrave para a economia nos anos I980, as estatais se transformaram em líderes de mercado, com competitividade internacional, e constituíram uma forte barreira para o capitalismo global no século XXI. Embora o consumo como porcentagem do gasto agregado tenha caído, a taxa média anual de crescimento do consumo foi de 9,2\% entre 1978 e 20I3 (LO, 20I6a, p. 247). Lo (20I6a) concluiu que a dupla meta de crescimento econômico sustentável e expansão compensatória do emprego foi amplamente conquistada graças à transição de um crescimento intensivo em força de trabalho para um crescimento com intensificação de capital desde meados dos anos 1990.

Tanto internamente quanto no exterior, o setor estatal chinês representou um papel importante ao romper com as práticas neoliberais e aderir à política de Estado, ou planificação. Seu contrapeso à ordem econômica neoliberal foi ignorado pela maior parte dos teóricos heterodoxos. Este artigo examina as anomalias e as origens da acumulação primitiva socialista. Argumenta-se que a adoção da reforma de mercado pela China ajudou a construir um setor estatal forte e não capitalista, que representa uma diferença fundamental em relação à acumulação capitalista. Essas duas tendências incompatíveis existem em uma economia política na qual a acumulação capitalista é um tipo de acumulação subordinado. A reforma de mercado é um meio- 
-termo estratégico, conforme se explicará nas seções 3.4 e 3.5; a China estava perto do limite dos seus meios internos para a acumulação primitiva socialista e seus líderes decidiram então alcançar os Estados Unidos em comércio global, tecnologia estrangeira e investimento. A reforma de mercado, incluindo a liberalização do mercado de trabalho, facilita a acumulação capitalista doméstica e internacional, mas também avança a acumulação primitiva socialista no sentido de que o setor estatal aumenta significativamente o valor de seus bens, a produtividade de sua mão de obra e sua competitividade. A teoria da acumulação primitiva socialista teve origem com a abordagem que Preobrazhensky faz da "Nova Política Econômica". Ele argumenta que, depois de depor o governo capitalista, uma economia de transição exige recursos externos ao seu sistema para ajudar a cimentar a base material para o socialismo, daí a acumulação primitiva socialista. Ainda assim, a acumulação primitiva socialista só pode criar as precondições para o socialismo, e não produzir automaticamente a transição para o socialismo, já que esse resultado depende da rivalidade entre tendências e classes sociais concorrentes, não apenas na China, mas em uma escala global.

Em seguida a esta introdução, a seção 2 do artigo examina as duas principais teorias heterodoxas do desenvolvimento econômico chinês, a seção 3 discute as anomalias reveladas por essas teorias e a seção 4 argumenta que a teoria da acumulação primitiva socialista pode explicar a razão dessas anomalias.

\section{A CHINA COMO PARCEIRA NO SISTEMA CAPITALISTA GLOBAL}

Esta seção discute as principais teorias a respeito da incorporação da China ao sistema capitalista global: I) como parceira da globalização neoliberal comandada pelos EUA; e 2) como modelo variante no sistema capitalista global.

\section{I. A China como parte do capitalismo global}

Em oposição à visão dominante de que o Estado não cumpre mais um papel na era da globalização, alguns economistas e cientistas políticos heterodoxos (JESSOP, 20I0; WOOD, 2005; PANITCH; GINDIN, 20I2) assinalam que Estados nacionais são importantes na formação e manutenção do sistema capitalista global contemporâneo. Estados nacionais se alinham aos interesses do capital global, adotam a reforma neoliberal e buscam ativamente eliminar ou reduzir drasticamente o papel do Estado na economia. Ao mesmo tempo, o Estado assumiu a responsabilidade de manter as insatisfações sob controle e de lidar com problemas sociais, econômicos e políticos criados e intensificados pela desregulamentação e flexibilização. Os Estados nacionais contribuem para isso ao promoverem a acumulação de capital de maneira a contribuir com a gestão da ordem capitalista internacional por parte dos EUA (PANITCH; GINDIN, 20I2, p. 8). Os Estados Unidos não precisam exercer o domínio colonial direto sobre outros Estados, já que as instituições internacionais instaladas após a Segunda Guerra Mundial são poderosas o suficiente para manterem os outros 
na linha e atuarem de acordo com os interesses do capital financeiro, uma vez que os Estados capitalistas têm interesse no sucesso da acumulação de capital e assumem a responsabilidade de criar o ambiente para a acumulação capitalista (PANITCH; GINDIN 20I2, p. 7, II). Esses autores acreditam que a internacionalização do Estado e a interpenetração do capital tornam muito pouco provável o surgimento de desafios ao império estadunidense - o maior garantidor global dos interesses capitalistas —, apesar da competição econômica entre capitais nacionais. Panitch e Giddin argumentam que a China colaborou voluntariamente com o capital global, o que levou a mudanças globais na estrutura industrial e nos preços das commodities: o aumento do investimento de capital depois da entrada da China na Organização Mundial do Comércio veio de corporações multinacionais que queriam usar a China como uma plataforma de exportação. O dramático desenvolvimento capitalista da China afetou a atividade econômica em todos os lugares, forçando a reestruturação industrial não apenas domesticamente, mas também no exterior, e determinando os preços globais de commodities. As "portas abertas" da China no início do século XXI foram completamente diferentes das de um século antes porque desta vez o capital global entrou a convite (PANITCH; GIDIN, 20I2, p. 293-296).

Como maior comprador de títulos do Tesouro dos EUA, o capital chinês é uma importante fonte de renda para o capital financeiro estadunidense e ajuda a manter a dominância dos Estados Unidos no sistema financeiro global. O caminho escolhido pelo governo chinês reforça a hegemonia dos EUA e ao mesmo tempo prejudica gravemente sua produção doméstica e sua capacidade de consumo. Conforme ilustram Panitch e Gindin, o maior fluxo de capital provindo do mundo em desenvolvimento tomou a forma de compras muito maiores de títulos do Tesouro estadunidense. Foi também uma condição necessária do desenvolvimento bem-sucedido do capitalismo orientado para a exportação. Como as exigências do livre comércio neoliberal implicavam o fim da proteção dos seus mercados domésticos de manufaturas contra os produtos importados, a preocupação em restringir a importação de bens de consumo e ao mesmo tempo acelerar a competitividade de exportação exigia limitar a renda da classe trabalhadora (PANITCH; GINDIN 20I2, p. 286).

\section{I.I. Um regime de trabalho neoliberal}

O livre fluxo de capitais gerou uma busca global por mão de obra barata. A mão de obra é submetida à competição internacional e a um regime trabalhista no qual salários são mantidos em estagnação enquanto os ganhos do capital disparam - uma das muitas características do neoliberalismo; destruir ganhos que as classes trabalhadoras tiveram no passado é a base dessa doutrina. A abertura da China permitiu uma nova divisão internacional do trabalho e a realocação do setor de produção de base do mundo em desenvolvimento. Isso, combinado com o crescimento de produtividade em países desenvolvidos, resultou na queda do emprego no setor de manufatura nesses países (SMITH, 2016). 
A reforma de mercado chinesa em 1978 resultou em uma mudança dramática no mercado de trabalho. A mão de obra rural não era mais impedida de viajar para fora de sua área de registro ${ }^{1}$ lhe foi permitido encontrar ocupações nas cidades, embora o registro de domicílio rural dessas pessoas continue existindo e elas, portanto, não sejam cobertas pelos serviços sociais das cidades. O fluxo de centenas de milhões de trabalhadores migrantes na China se tornou uma grande fonte de mão de obra barata em escala global. Os trabalhadores migrantes se tornaram uma ampla reserva de força de trabalho e são mais propensos a aceitar salários baixos e condições de trabalho precárias, uma vez que têm menos direitos e menor provisão de bem-estar social que os trabalhadores urbanos formalmente registrados. O relatório de monitoramento nacional dos trabalhadores migrantes mostra que havia 277 milhões de trabalhadores migrantes na China em 20I5, e 63,8\% deles não tinham contrato (NBS, 20I6b); I2,9\% tinham contratos permanentes; $3,4 \%$, temporários por menos de I ano; e I9,9\%, temporários por mais de I ano (NBS, 20I6b). Apenas I,I\% dos trabalhadores migrantes não tinham educação formal, quase $60 \%$ tinham pelo menos o nível secundário, e $8,3 \%$, formação superior (NBS, 20I6b). O maior grupo de trabalhadores migrantes, 31,3\%, ou seja, mais de 86 milhões, trabalhavam na indústria manufatureira (NBS, 20I6b). A reestruturação do regime de trabalho não está confinada ao setor privado.

A reforma das estatais nos anos 1990 também levou à privatização e fechamento de um grande número de estatais de pequeno e médio porte, e milhões de antigos funcionários públicos se tornaram supérfluos no processo. Como resumido por Andreas, o impacto da reforma das estatais, agravado pela aceitação da China na OMC, significou que tanto as empresas privadas como as estatais foram submetidas à competição de mercado. Segundo o autor, a entrada da China na OMC, em 200I, seguida por uma abolição mais sistemática dos impedimentos legais ao comércio e investimento internacional, deu força às reformas de mercado ao submeter mais profundamente as empresas chinesas à competição internacional. Com poucas exceções, todas as firmas foram obrigadas a reduzir o custo do trabalho e das obrigações sociais que não contribuíam diretamente para o lucro. Segundo Andreas, como resultado das reformas radicais feitas nos últimos anos, a economia de mercado não capitalista que existia nos anos 1980 foi transformada em economia capitalista. Não haveria mais um setor socialista, e virtualmente todas as empresas, públicas ou privadas, que empregam mais do que um punhado de pessoas agora estariam operando de acordo com princípios capitalistas (ANDREAS, 2008).

Muitos estudos mostraram que os trabalhadores saíram perdendo na reforma de mercado. Os teóricos do capitalismo global argumentam que a "corrida para o fundo" em escala global se tornou possível, em larga medida, em razão de a China ter aberto seu mercado de trabalho. Uma força de trabalho relativamente educada e especializada, inacessível ao capital no passado, formou um enorme exército de reser-

\footnotetext{
O sistema hukou (registro de residência) estava firmemente em vigor antes de 1978, durante o período maoista, quando cidadãos chineses não podiam viajar para além de sua área de registro nem trabalhar fora dela sem permissão.
} 


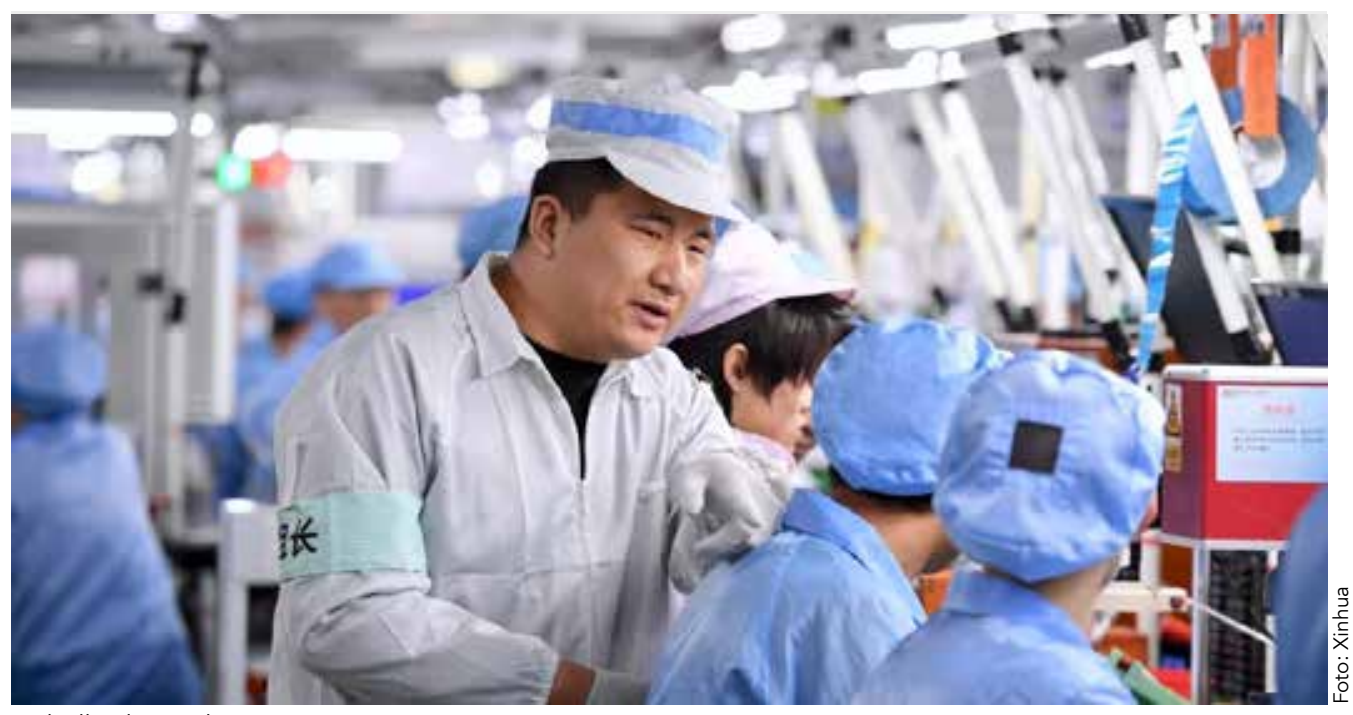

Trabalhadores chineses

va - tanto que a mão de obra barata da China se tornou uma oportunidade de ouro para o capital estrangeiro. No entanto, deve-se lembrar que é a lei do lucro que move o capital, não a mão de obra barata ${ }^{2}$.

\section{I.2. "Go global" (seja global) como sintoma da superprodução}

Segundo esses teóricos heterodoxos, o aumento dos investimentos no exterior por parte das empresas chinesas na virada do século pareceu demonstrar seu crescente alinhamento com a ordem econômica global e constitui uma preocupante reprodução de poder imperialista.

Sendo a potência manufatureira do mundo, a China precisa importar matéria-prima para sustentar seu nível de produção. A importação contínua de commodities primários pela China tem sido uma fonte importante de renda para alguns países em desenvolvimento, especialmente durante a recessão global, e contribuiu positivamente para os termos de troca dos países em desenvolvimento (LO, 20I6b).

Apesar disso, alguns podem achar que o padrão de comércio entre a China e os países em desenvolvimento tem aparência de um relacionamento assimétrico no qual os países em desenvolvimento exportam commodities primárias e importam bens manufaturados. Sendo um país de desenvolvimento tardio, a China aparentemente segue o modelo de produção em massa e baixo consumo doméstico, e, portanto, precisa dos mercados estrangeiros para obter recursos e exportar, como todo mundo. Como Hart-Landsberg e Burkett (2005, p. II2) elaboram: analistas tradicionais nem sequer param para refletir na coexistência, no crescimento da China, entre superprodução (refletida na deflação e na crescente capacidade de produzir excedentes, especialmente nas indústrias de bens de consumo duráveis) e aumento da intensidade de

\footnotetext{
Como explicado por Marx no volume 3 de O Capital, o investimento de capital no exterior é uma estratégia para contrabalançar a influência da queda da taxa de lucro. Ver mais explicações em Carchedi e Roberts (2018).
} 
exportações como possível sintoma de mau funcionamento mais profundo, especialmente dado o aumento contínuo da desigualdade. Na realidade, como a experiência chinesa fortemente demonstra, a superprodução e a dependência de exportações são resultados gêmeos da tendência capitalista a desenvolver forças produtivas apenas mediante a exploração do trabalho e suas condições naturais e sociais, um processo que restringe o crescimento do mercado de massa em relação à capacidade produtiva.

Além da necessidade de mercados estrangeiros e recursos, o fluxo externo de capital é visto como mais um sinal de superacumulação capitalista. Segundo Harvey (2007, p. I4), os excedentes acumulados da China ou estão patrocinando a dívida dos EUA, e, portanto, o mercado estadunidense para bens chineses, ou são investidos no exterior para garantir a posição do país nos mercados estrangeiros. Segundo um relatório da Comissão de Avaliação de Segurança e Economia Estados Unidos-China, a maior parte das reservas de câmbio da China no exterior é investida em títulos do Tesouro estadunidense (SALIDJANOVA, 20II, p. I4). Embora a Corporação de Investimento da China (CIC), criada em setembro de 20I7, tenha como objetivo diversificar as reservas estrangeiras, a maioria de seus investimentos globais ainda é em títulos públicos, e os títulos estadunidenses correspondem à maior parte dos títulos do CIC, com $46,32 \%$ no final de 2015 , uma ligeira melhora em relação aos $49,2 \%$ verificados em 2012 (CIC, 2012; 20I5).

Em contraste com o fundo soberano de riquezas, no final de 2014 a maioria $(82,5 \%)$ do estoque de IEDs chineses era investida no mundo em desenvolvimento, e as estatais respondiam por 53,6\% desses investimentos (MOFCOM, 2015, p. 20, 26). A construção e o desenvolvimento de infraestrutura em larga escala envolvidos nesses investimentos no mundo em desenvolvimento exigem comprometimento de capital de longo prazo e geram um retorno relativamente baixo quando comparado com o dos investimentos de portfólio.

Os investimentos chineses em mercados financeiros e em projetos de construção e infraestrutura em larga escala representam a existência de duas tendências conflitantes na acumulação. Em uma economia em que há acumulação capitalista, a pressão para que o capital chinês privado se acumule seria a mesma que sobre qualquer outro capital privado, e, portanto, segue a tendência de financeirização. A superacumulação pode ser um motivo para a fuga de capital e para a busca de mercados e recursos estrangeiros. No entanto, como é defendido na parte final deste artigo, a acumulação capitalista pode não ser a única modalidade de acumulação na China; se o excesso de acumulação não estiver alavancando o investimento externo, o que mais o estará alavancando? Com o crescimento da produtividade, poderia o excedente de produto em relação à demanda doméstica ser usado para facilitar a acumulação do setor estatal? Poderia o comércio exterior ser parte de um plano de economia socialista?

Em sua tese Is China still socialist?: a Marxist critique of János Kornai’s analysis of China (a China ainda é socialista? Uma crítica marxista à análise de János Kornai sobre a China), Khoo (20I8) argumenta que em uma "economia commodity-socia- 
lista" mista, na qual a produção capitalista não é o modo dominante de produção e está competindo com a economia coletivizada, há uma interação necessária entre o setor privado e o setor estatal. A acumulação em favor do setor estatal se baseia no intercâmbio desigual no âmbito de seu processo de produção, à custa do setor privado, embora este último resista vigorosamente para evitar a acumulação ótima no setor estatal. Enquanto a acumulação capitalista acontece no setor privado, o setor estatal precisaria produzir um excedente de produtos para consumo e para expandir empresas estatais já existentes. Os novos recursos exigem tal expansão e não estão confinados ao setor estatal, mas precisam ser tirados do setor privado doméstico e externo, especialmente em economias nas quais as desproporções internas e o atraso industrial exigem importações para aliviar a situação (KHOO 20I8, p. 198). Sob tal circunstância, importações planejadas de meios de produção se tornam um regulador automático de todo o processo de reprodução expandida (KHOO, 20I8, p. 198).

A política "seja global" (zou chu qu) foi introduzida no Décimo Plano Quinquenal da China, em 20or. Seus quatro objetivos estão claramente expostos em uma circular oficial de 2004, que encoraja empresas chinesas a investir no exterior, particularmente em: I) recursos primários que faltam à China; 2) áreas que podem permitir a exportação de bens e tecnologia chinesas com vantagens comparativas; e 3) áreas que podem permitir o desenvolvimento de pesquisa e desenvolvimento chineses com tecnologia moderna e gerência de habilidades (NDRC et al., 2006).

Para críticos como Harvey (2004), o princípio da planificação da economia estatal chinesa não se diferencia do princípio da acumulação de capital. A presença do Estado no processo de acumulação de capital só mostra diferença quanto às novas formas de acumulação de capital. Tais autores veem a China como uma versão moderna da Alemanha de Bismarck ou do Japão da era Meiji, quando o Estado esteve ativamente envolvido na criação de conglomerados domésticos (HARVEY, 2004), embora os conglomerados chineses sejam, em geral, do Estado.

\subsection{A China como uma variante do modelo capitalista global contemporâneo}

Enquanto alguns teóricos heterodoxos acreditam que a China é um parceiro indispensável para a sustentação e o reforço do capitalismo global comandado pelos Estados Unidos no século XXI, outros reconhecem essa potência emergente como uma variante, acreditando que as diferenças residem na forma de capitalismo.

\subsection{Sinocapitalismo}

McNally (20I2) descreve o caminho do desenvolvimento econômico da China como um sinocapitalismo, híbrido que consiste em vários arranjos institucionais compensatórios inter-relacionados e codependentes (MCNALLY, 20I2, p. 749). É uma nova forma de capitalismo que se baseia elementos ocidentais, asiáticos, socialistas e chineses, históricos e modernos (MCNALLY, 20I2, p. 748). Há três características 
principais no sinocapitalismo: I) o uso intenso de relações interpessoais (guanxi) para formar e fazer proliferar redes de negócios informais com alcance global; 2) o papel de liderança do Estado ao promover e guiar a acumulação capitalista; e 3) alguma absorção das instituições e valores anglo-americanos para formar um híbrido, uma forma liberal de mercado do capitalismo de Estado (MCNALLY, 2012, p. 750).

McNally explica que o sinocapitalismo vê os mercados como meras ferramentas em uma estratégia mais ampla e guiada pelo Estado para criar uma política econômica competitiva internacionalmente (MCNALLY, 20I2, p. 766). O Estado chinês não apenas manteve o controle do alto comando da economia durante todo o período de reforma, mas também utilizou um mecanismo efetivo de indicação de pessoal do Partido Comunista (nomenklatura) para encorajar os quadros a melhorar a performance econômica local. Há também instituições para implementar políticas industriais centrais. Pode não haver uma fórmula fixa no sinocapitalismo, uma vez que a liderança chinesa adotou uma abordagem cuidadosa e experimental, que McNally chama de "neoestatista", planejando com experimentação política exploradora e inovadora (MCNALLY, 20I2, p. 754). No entanto, ele deixa claro que isso não é anticapitalista: certamente, afirma, um sistema como um todo pode ser capitalista mesmo guiado por influências de Estado, tais como planejamento estatal indicativo, propriedade pública do alto comando da economia e uso estratégico de incentivos fiscais estatais (MCNALLY, 2012, p. 747).

Tal visão é compartilhada por aqueles que, embora aceitando que o sistema chinês seja muito distinto, acreditam que ele é ainda assim apenas uma variante do capitalismo. Ten Brink (20I4, p. 222) acredita que há alguns legados da economia de comando burocrático que explicam a intervenção estatal intensiva em busca de desenvolvimento comandado pelo mercado. Ten Brink (20I4, p. 22I) afirma que essa é uma variação guiada pela competição no desenvolvimento capitalista heterogêneo permeado pelo Estado. Portanto, a intervenção estatal ou a propriedade estatal não negam as relações capitalistas. A reestruturação da valorização do capital pode desafiar as constelações estabelecidas nas instituições internacionais, mas o alinhamento pragmático da China teve como objetivo a integração tanto normativa quanto política, o que não representa um concurso aberto a respeito de novas políticas de desenvolvimento (TEN BRINK, 20I4, p. 230).

\subsubsection{Corporativismo de Estado}

Os teóricos do corporativismo de Estado têm uma visão semelhante à daqueles que acreditam que a China é parte integrante do capitalismo global, mas para os primeiros o Estado autoritário pode pôr o interesse nacional acima dos interesses paroquiais de cada setor e é capaz de reforçar a disciplina. Assim, a China pode se tornar um Estado corporativista por causa de seu regime autoritário sob o Partido Comunista (UNGER; CHAN, I995, p. 32). Segundo Unger (2008, p. 7), um Estado corporativista é um Estado que domina as associações na esfera pública, e às vezes tem até 
um papel importante em estabelecê-las. O controle que o Estado tem das associações pode, potencialmente, torná-las veículos para reduzir a capacidade da sociedade civil de operar efetivamente e de forma independente do Estado.

Unger e Chan (I995, p. 37-38) acham que os sindicatos industriais e associações de camponeses estabelecidos no início da era Mao serviam a uma via de mão dupla entre o centro do partido e seus constituintes designados, e já eram parte de uma estrutura corporativista. Durante os anos I980, milhares de associações, da ciência e tecnologia aos setores econômicos em diferentes indústrias, foram estabelecidas como mecanismos adicionais de controle do Estado sobre a sociedade na economia liberalizada. Os autores argumentam que a China tem muitas características em comum com os Estados corporativistas do leste da Ásia, como o Japão, a Coreia do Sul e Taiwan, em termos de envolvimento ativo do Estado para garantir a competitividade da indústria, a busca de um crescimento orientado para a exportação e a subordinação de todas as classes sociais ao bem comum do crescimento econômico. No entanto, em contraste com os Estados corporativistas do Leste Asiático, que foram na direção de um corporativismo social, questiona-se se a China vai se tornar um Estado corporativista liberal ou social com o avanço da liberalização (UNGER; CHAN, I995).

Contudo, alguns acadêmicos (PRINGLE, 20I4; LUTHJE, 20I5) argumentam que a classe trabalhadora chinesa não está totalmente incorporada ao poder, embora a Federação dos Sindicatos, comandada pelo Partido Comunista, seja a única organização de trabalhadores legal na China. Pringle (20I4, p. 199) mostra que, em alguns casos, o sindicato oficial foi pressionado pelos trabalhadores a melhorar sua capacidade de representá-los, inclusive com uma greve de i9 dias na fábrica de autopeças da Honda em Foshan, em 20I0, e a parada de 33 horas nos Terminais de Contêineres Internacionais de Yantian, em 2007. Luthje (20I5, p. 32) pensa que a estrutura de atores coletivos nas relações de trabalho permanece confinada a seu papel tradicional de agência estatal de facto, e não pode agir como representante dos interesses de grupo ou classe no sentido básico das teorias de relações industriais. Assim, a China falha em copiar o corporativismo alemão, ou seja, em criar um mecanismo tripartite conforme o qual governo, sindicatos e organizações patronais colaborem na regulação de normas básicas de trabalho. $\mathrm{O}$ autor acredita que a mão de obra na China é uma força relativamente independente e descreve os trabalhadores como uma quarta parte que exerce considerável pressão moral ou política sobre as agências estatais por meio de indivíduos ou grupos de indivíduos que agem mediante processos, greves, protestos e petições (LUTHJE, 20I5, p. 32).

Apesar das diferenças entre os acadêmicos citados quanto à interpretação da situação da classe trabalhadora na economia política chinesa, todos concordam que as forças do trabalho dependem da liberdade de associação e do crescimento da sociedade e dos atores civis. No entanto, o debate sobre o corporativismo foca o tipo de quadro institucional que regula as relações de trabalho sob o capitalismo. Expõe a preferência dos teóricos por um esquema tripartite social-democrata, mas não tem 

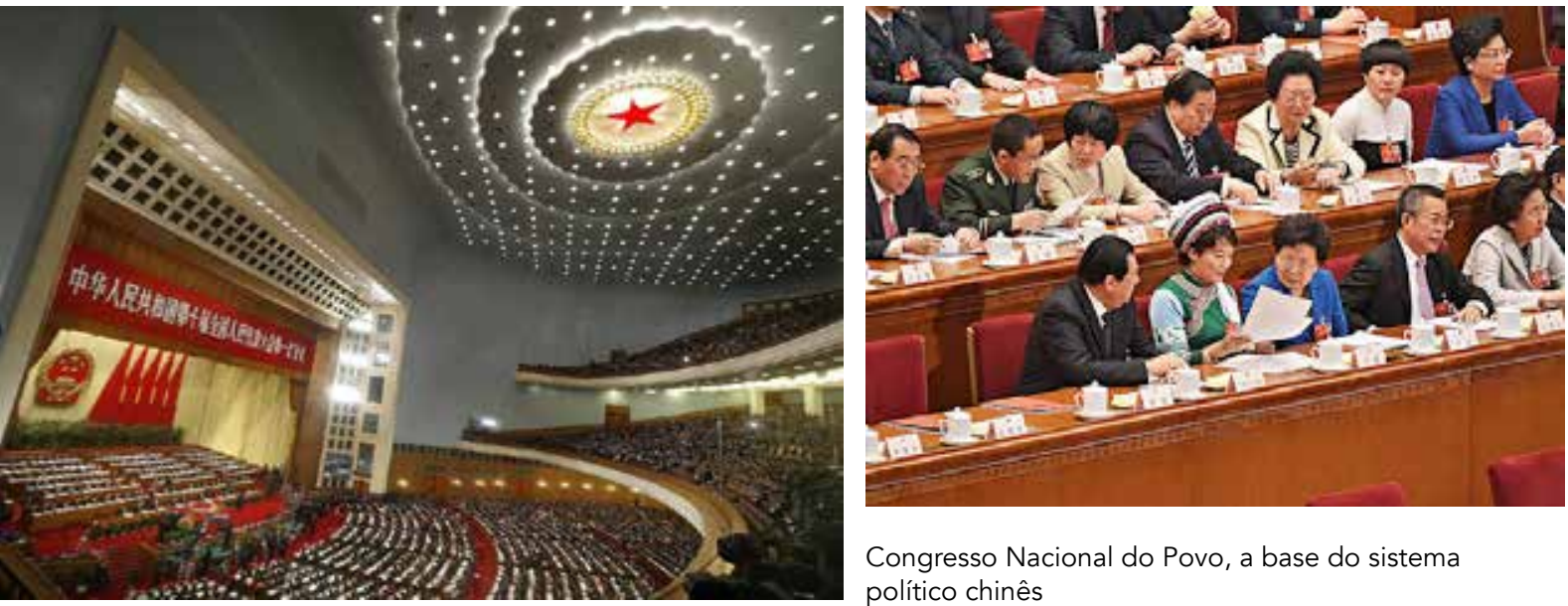

Congresso Nacional do Povo, a base do sistema político chinês

poder para explicar o que está acontecendo na China. O modelo corporativista de Estado observou a dominância do Estado sobre diferentes classes durante o processo de acumulação. Tal dominância é percebida por esses teóricos como aparentemente independente, mas que na verdade está ao lado do capital contra a mão de obra, já que toda acumulação é identificada com exploração.

No entanto, Lo e Zhang (20II) argumentam que as estatais chinesas constituem uma parte importante e igualitária das características sistêmicas da China, apresentando o caráter de suplantar o mercado. A diferença mais notável é que as instituições das estatais desviaram-se significativamente dos princípios da economia de mercado, notadamente o do direito de propriedade individual (LO; ZHANG, 20II, p. 47).

Enquanto Unger e Chan (I995, p. 43) preveem que as estatais lucrativas estarão mais bem posicionadas para se afirmarem coletivamente e que os controles corporativistas de cima para baixo diminuirão constantemente, a resposta do Estado chinês à recessão global, dos projetos de infra-estrutura em grande escala até a iniciativa da "Nova Rota da Seda", mostraram que o Estado ainda exerce amplo controle sobre as estatais e o setor bancário.

\section{AS ANOMALIAS DA VIA CHINESA PARA O CRESCIMENTO E O DESENVOLVIMENTO ECONÔMICO}

Os teóricos citados avaliam as anomalias do sistema político-econômico da China em diferentes graus. Todos eles acreditam que as variações não se desviam essencialmente da acumulação capitalista, seja competindo ou complementando o capitalismo global comandado pelos Estados Unidos. Ao passo que chamaram a atenção para o custo humano da reforma de mercado da China e para o domínio da ordem e ideologia capitalistas em escala global, esses acadêmicos ignoraram a natu- 
reza seletiva da integração e participação no sistema e, mais importante, o papel da acumulação primitiva socialista e da planificação estatal.

\section{I. Investimento estatal em infraestrutura}

Embora Harvey (2007, p. I40) descreva a China como um Estado neoliberal, ao mesmo tempo ele concorda que a China se afasta notavelmente do padrão neoliberal, especialmente graças a seu enorme investimento em infraestrutura, por mais insustentável que isso eventualmente possa ser. Lo (2012; 20I6b) sugere que o investimento da China na formação de capital não é insustentável, mas sim a chave para sua contínua resistência às dinâmicas sistêmicas do capitalismo global. É esse investimento produtivo e o crescimento da produtividade que permite à China se afastar do modelo de crescimento com mão de obra intensiva e, portanto, superexploração.

Lo (20I6b) também argumenta que a China teve um impacto positivo no mundo em desenvolvimento. Seu investimento produtivo não segue a norma da especulação financeira na era da globalização. O barateamento de bens de produção, como maquinário e equipamento, que são essenciais para a industrialização, também contribui para favorecer os termos de troca dos países em desenvolvimento. $\mathrm{O}$ investimento chinês em infraestrutura continuou a crescer por décadas, e o pacote de estímulo de trilhões de yuans anunciado pelo governo em face da recessão global de 2008 aplicou ainda mais investimentos na infraestrutura. Em 20I6, o governo prometeu mais 4,7 trilhões de renmimbis para 303 projetos de infraestrutura, incluindo ferrovias, estradas, vias aquáticas, aeroportos e sistemas de metrô (LOCKETT, 20I6). O crescimento rápido e sustentado do investimento produtivo é muito mais importante do que a mão de obra barata para impulsionar as exportações e o crescimento econômico. Assim, a China é um dissidente na era da financeirização (LO, 2016, p. 13). A China gastou US\$ 3,6 trilhões em infraestrutura em 20I5, o equivalente aos gastos totais da América do Norte e Europa Ocidental, os blocos principais no comércio capitalista desenvolvido, segundo um relatório do Instituto McKinsey Global (WOETZEL et al., 20I7). Isso não é passageiro ou experimental, mas uma característica consistente do desenvolvimento econômico chinês.

\subsection{A China não depende principalmente de exportações para crescer}

Com o aumento do consumo, não é mais exato descrever a China como uma economia de exportação. A renda per capita disponível na China cresceu de I4.55I para 2I.966 yuans entre 20II e 20I5. Em 20I5, a taxa média de crescimento real anual da renda disponível foi de $6,6 \%$ para lares urbanos permanentes e de $7,5 \%$ para lares rurais (NBS, 20I6a). Em uma pesquisa citada por The Economist (STILL..., 20I6), esperava-se que a economia de consumo da China se expandisse para US\$ 2,3 trilhões nos cinco anos seguintes, o que seria maior que toda a economia de consumo da Grã-Bretanha ou da Alemanha hoje. Um relatório especial do Financial Times também mostra que o consumo doméstico da China cresceu de $13 \%$ do nível estadunidense em 2007 para 
34\% em 20I7, e essa diferença está diminuindo (WOLF, 20I8). O consumo doméstico representa $70 \%$ do consumo final (que consiste em consumo doméstico mais consumo governamental) desde 1978 (ex: 78,8\% em I978; 73,I\% em 20I6), e apresenta uma impressionante taxa de crescimento real médio anual, de 9,3\% entre 1978 e 2013 (LO, 20I6a, p. 247). Ao mesmo tempo, a China viu um crescimento da formação de capital fixo bruto como porcentagem do PIB, de 30\% em 1978 para $43 \%$ em 2016 (NBS, 20I7b).

Levando em conta a distribuição da composição do PIB, parece haver uma redução de consumo, mas isso pode ser enganador. Na tabela I, em 1955 o consumo doméstico revela-se responsável pela maior fatia do $\mathrm{PIB}, 64 \%$, mas isso não significa que o padrão de vida geral ou o consumo doméstico eram mais altos em 1955 do que em 2016.

Tabela 1. PIB da China e sua composição, por áreas selecionadas, 1955-2016

\begin{tabular}{lcccc}
\hline & $\begin{array}{c}\text { PIB (milhões de yuans, } \\
\text { em preços correntes) }\end{array}$ & $\begin{array}{c}\text { Consumo final } \\
\text { (\% do PIB) }\end{array}$ & $\begin{array}{c}\text { Consumo doméstico } \\
\text { (\% do PIB) }\end{array}$ & $\begin{array}{c}\text { Formação bruta de } \\
\text { capital fixo (\% do PIB) }\end{array}$ \\
\hline $\mathbf{1 9 5 5}$ & 93.490 & 77 & 64 & 16 \\
$\mathbf{1 9 6 0}$ & 150.800 & 62 & 49 & 31 \\
$\mathbf{1 9 6 5}$ & 162.920 & 71 & 58 & 21 \\
$\mathbf{1 9 7 0}$ & 220.700 & 66 & 55 & 25 \\
$\mathbf{1 9 7 5}$ & 295.040 & 64 & 52 & 30 \\
$\mathbf{1 9 8 0}$ & 459.290 & 65 & 51 & 29 \\
$\mathbf{1 9 8 5}$ & 907.670 & 66 & 52 & 29 \\
$\mathbf{1 9 9 0}$ & 1.934 .780 & 62 & 49 & 25 \\
$\mathbf{1 9 9 5}$ & 6.321 .690 & 58 & 45 & 33 \\
$\mathbf{2 0 0 0}$ & 9.874 .900 & 62 & 46 & 34 \\
$\mathbf{2 0 0 5}$ & 18.869 .210 & 52 & 38 & 41 \\
$\mathbf{2 0 1 0}$ & 41.070 .800 & 48 & 36 & 45 \\
$\mathbf{2 0 1 5}$ & 69.910 .900 & 52 & 38 & 43 \\
$\mathbf{2 0 1 6}$ & 74.631 .500 & 54 & 39 & 43 \\
\hline
\end{tabular}

Fonte: China compendium of statistics 2009; China statistical yearbook 2017. Cálculos da autora.

$\mathrm{Na}$ verdade, dados recentes do China statistical yearbook 2018 mostram que houve um crescimento contínuo do consumo doméstico tanto urbano quanto rural entre 1978 e 20I7, como indica o gráfico I (NBS, 20I8). 
Embora parte da via chinesa para a industrialização coincida com a de alguns Estados desenvolvimentistas do leste da Ásia, por exemplo, pela dependência de mão de obra barata e de investimento externo, há também uma diferença significativa entre ambas, já que a industrialização chinesa não é inteiramente dependente do capital estrangeiro ou de mercados estrangeiros

Gráfico 1. Crescimento do consumo doméstico na China, 1978-2017

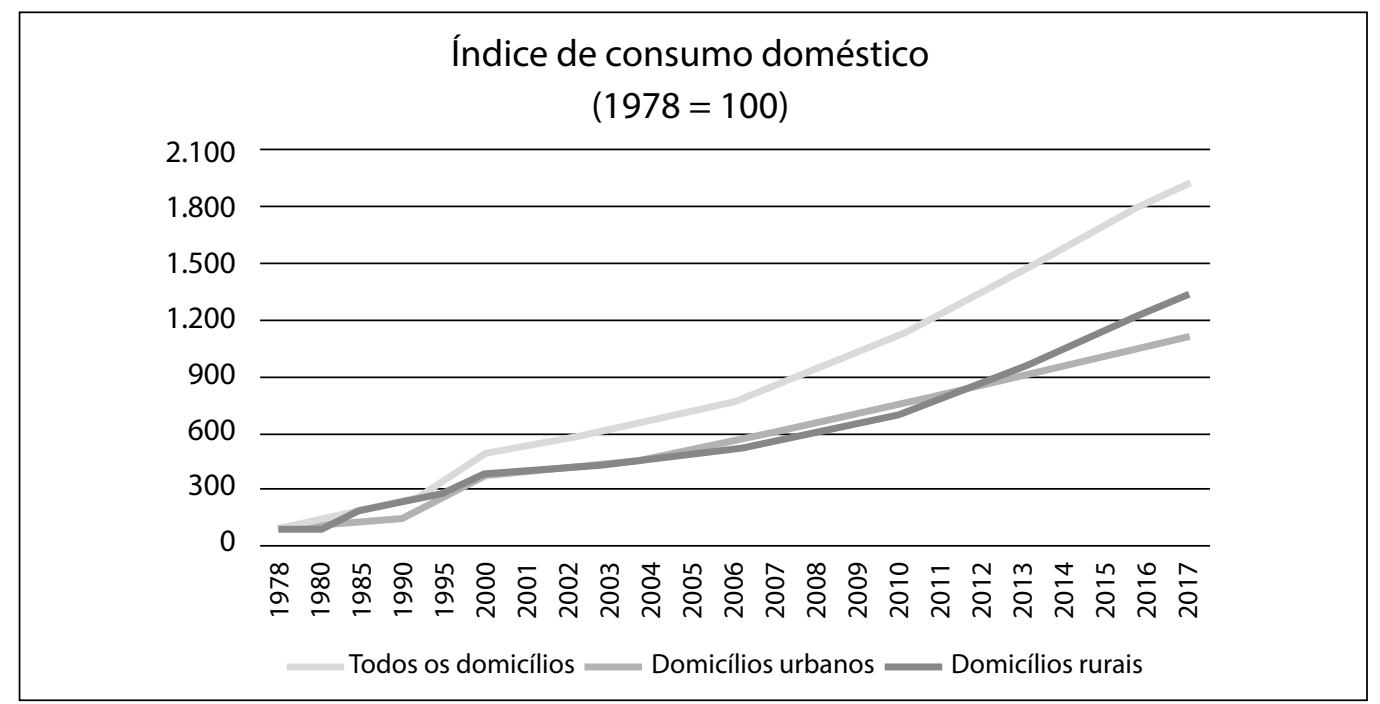

Fonte: China statistical yearbook 2018.

A expectativa de vida no nascimento também sofreu um aumento significativo, indo de 43,7 anos em I960 para 76,25 anos em 20I6, segundo dados do Banco Mundial. Os dados sobre participação no crescimento do $\mathrm{PIB}^{3}$ provam ainda que o consumo final tem sido o principal motor do crescimento econômico desde 20I4, ultrapassando a formação de capital bruto e a exportação líquida de bens e serviços, como mostra o gráfico 2.

3 Segundo o China statistical yearbook 2018, a definição da parcela de contribuição dos três componentes para o aumento do PIB se refere à proporção do incremento de cada componente do PIB pela ótica dos gastos no aumento do PIB. 


\section{Gráfico 2. Participação dos três componentes do PIB no crescimento econômico da China, 1978-2017}

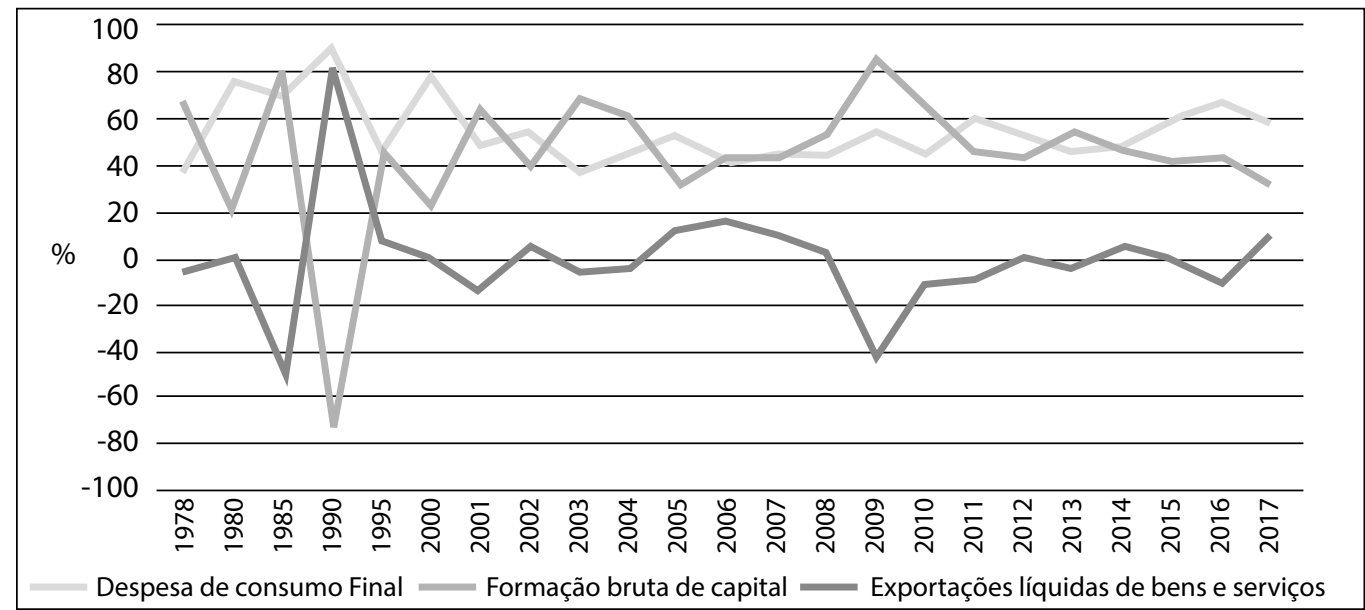

Fonte: China statistical yearbook 2018.

Bramall (2009, p. 276) sugere que, embora o discurso de crescimento orientação por exportações possa ser aplicado a Guangdong, não vale para províncias como Zheijang e Jiangsu, pois lá os fatores domésticos foram críticos. A exportação de bens e serviços como porcentagem do PIB na China chegou ao ponto alto de $36 \% \mathrm{em} 2006$ e caiu desde então. Apenas entre 2002 e 2008 essa porcentagem na China excedeu a média mundial (gráfico 3).

Gráfico 3. Exportações de bens e serviços na China e no mundo, 1960-2016 (\% do PIB)

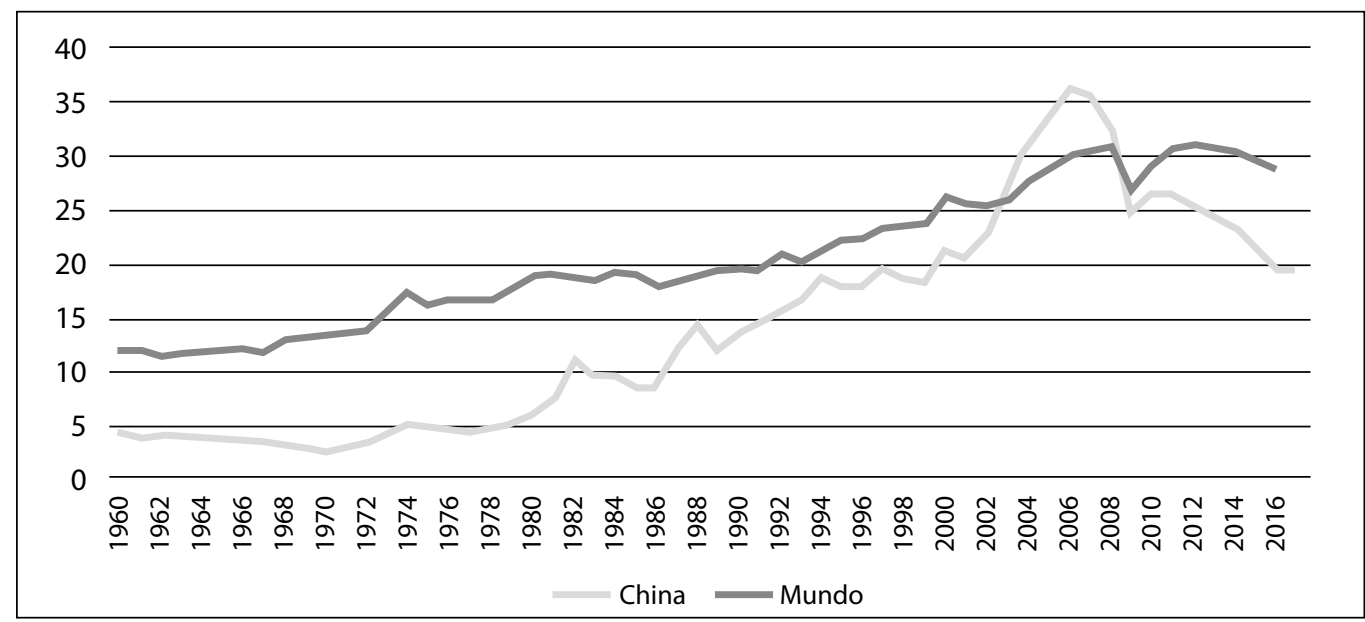

Fonte: World Bank (2016).

Embora parte da via chinesa para a industrialização coincida com a de alguns Estados desenvolvimentistas do leste da Ásia, por exemplo, pela dependência de mão de obra barata e de investimento externo, há também uma diferença significativa entre ambas, já que a industrialização chinesa não é inteiramente dependente do capital estrangeiro ou de mercados estrangeiros. No processo de integração com a economia 
regional e global, a China conseguiu lograr substituição de importações e modernização industrial e manter uma política financeira relativamente independente (LO, 2012, p. 92). Como destaca Lo (2016b, p. I3), medida como relação entre exportações líquidas e brutas, a proporção do comércio de valor agregado doméstico cresce constantemente, de cerca de $20 \%$ em meados dos anos 1990 até $45 \%$ em 2009. Isso também difere do caso dos Estados clientes dos EUA, como o Japão e a Coreia do Sul, que tiveram tratamento preferencial até o fim da Guerra Fria, no fim dos anos 1980, depois do que precisaram liberalizar seus mercados, incluindo as finanças externas. Como resultado, a Coreia do Sul sofreu sérios déficits nos anos 1990 (LO, 20I2, p. 90-94).

\subsection{O regime trabalhista em contexto}

A reconstituição da classe trabalhadora chinesa tem sido o foco do debate econômico heterodoxo para determinar a natureza da política econômica local. A composição da força de trabalho total mudou conforme o número de trabalhadores empregados no setor não estatal superou o do setor estatal e trabalhadores do setor estatal pareciam encarar problemas similares de precarização e intensificação do trabalho (LIN, 20I5). Embora existam evidências de um regime de trabalho neoliberal desde a reforma de mercado nos anos I980, a situação possui mais nuanças.

Como argumenta Lo (20I6), a China não adotou o regime trabalhista neoliberal completamente, e nem mesmo o modelo da Foxconn oferece uma representação adequada da situação de trabalho na China. Entre 2000 e 20I4, o crescimento médio anual da taxa de salário real foi de II,2\% para empregados registrados urbanos e de I0,3\% para trabalhadores migrantes, ambas mais altas que a do crescimento real médio anual do PIB, de 9,2\% (LO, 20I6a). O mais notável é que a Lei de Contrato Trabalhista, que oferece maior proteção para os trabalhadores, particularmente os trabalhadores migrantes, entrou em vigor em 2008, no auge da recessão global e sofrendo objeções do capital estrangeiro (LI, 2008). Lo e Zhang (20II) analisaram a composição das exportações chinesas de manufaturas em 2007 e descobriram que produtos mecânicos e eletrônicos representavam 6I\% do total, com um aumento de $30 \% \mathrm{em}$ 2006. Essas não são indústrias com trabalho intensivo ${ }^{4}$, e seu aumento na cesta das exportações indica que a China está se afastando da corrida pela mão de obra barata. Lo e Zhang (20II) mostram que o crescimento econômico da China na última década na verdade foi impulsionado por um crescimento da produtividade, em vez de uma corrida pela redução dos custos trabalhistas. O Global wage report 20I8/19, publicado pela Organização Internacional do Trabalho (ILO, 20I8b), mostra que, entre 2008 e 20I7, a China teve um crescimento médio real dos salários muito mais alto $(8,2 \%)$ que o da maior parte dos países do leste da Ásia e do resto dos Brics (Brasil: 2,2\%; Rússia: 2,5\%; África do Sul: 2,4\%; Índia: 5,5\%).

Usando o critério usual de produtividade relativa do trabalho, Lo e Zhang argumentam que o setor de maquinário não é de trabalho intensivo, enquanto a indústria de eletrônicos é de capital intensivo, já que seus índices relativos de produtividade do trabalho $(0,91$ e 1,25, respectivamente) são maiores que aquele $(0,9)$ usado para definir indústrias de trabalho intensivo (LO; ZHANG, 2011, p. 43). 
Críticos que identificam o trabalho assalariado nas estatais como prova do capitalismo chinês têm oferecido observações, mas não deram nenhuma sugestão nem explicaram condições para abrir mão do trabalho assalariado. Eles comparam o regime de trabalho da era pré-reforma com a liberalização durante a reforma de mercado e acreditam que isso representa uma mudança drástica de direção, rumo à superexploração. No entanto, o regime trabalhista antes das reformas de mercado era melhor e menos exploratório? A maior parte da força de trabalho antes de 1978 - na verdade, até 2014 - estava no setor rural. Esse setor tem sido uma fonte importante de acumulação para o programa de industrialização chinês, particularmente antes do afluxo de IEDs em larga escala. A priorização da industrialização exige a transferência de excedente do setor rural para o setor urbano. Isso se reflete no regime de trabalho camponês, no qual os níveis salariais permaneceram estagnados por mais de duas décadas e o preço dos produtos agrícolas foi artificialmente rebaixado para garantir um fornecimento barato de comida, como se explica na próxima seção.

\subsection{Acumulação primitiva socialista por meio do regime de trabalho camponês para a industrialização}

Como Chun (2006, p. 62-70) aponta, a situação internacional, incluindo o bloqueio comandado pelos Estados Unidos e, depois, a ruptura sino-soviética, empurrou a China para uma priorização da industrialização a quase qualquer custo, para se preparar para uma invasão estrangeira e minimizar a dependência econômica. Isso contrasta com as economias asiáticas recém-industrializadas, que se beneficiaram de grandes influxos de IED dos Estados Unidos e de um acesso sem precedentes ao mercado estadunidense. A China não tinha acesso a empréstimos de economias avançadas e, muito menos, capacidade de acumular reservas estrangeiras. A acumulação primitiva de capital para reconstruir o país depois de décadas de guerra e devastação foi levada a cabo pelo sacrifício do desenvolvimento rural e pela exploração do campesinato (LIN, 2006, p. 66). O excedente agrícola era transferido para os projetos de industrialização do Estado por meio de uma política que se parecia com as iníquas "tesouras de preço", pelas quais os preços dos produtos agrícolas e bens industrializados eram manipulados artificialmente para favorecer estes últimos por meio de um monopólio estatal de compras (LIN, 2006, p. 67).

Como explica Bramall (2009, p. 279), para atingir esse crescimento em prol de uma rápida industrialização foi necessário aumentar o investimento no setor industrial. Isso, por sua vez, exigia a maximização dos lucros industriais, e a melhor forma de obtê-la era manter os custos baixos. O principal item de custos era a mão de obra, e a forma mais fácil de mantê-los baixos era garantir que a comida dos trabalhadores urbanos fosse barata. A consequência dessas considerações foi uma política deliberada para enviesar os termos internos de troca - o preço da agricultura em relação aos bens industriais - em detrimento do setor agrícola.

Como resume Bramall (2009, p. 73), os níveis baixos de capital humano, as 
condições subdesenvolvidas da infraestrutura, a extensão da pobreza e da desigualdade (que exigiam uma ação imediata) e a baixa produtividade na agricultura inevitavelmente inibiram o ritmo do crescimento econômico nos anos 1950. A subindustrialização da China se refletia na distribuição dos seus empregos, como mostra o gráfico 4. O abismo entre rural e urbano na verdade aumentou durante o período maoista, mesmo antes das reformas de mercado, apesar de algumas tentativas para acelerar o desenvolvimento rural, como a shangshan xiaxiang (subida às montanhas, descida ao campo) e a Terceira Frente ${ }^{5}$ (BRAMALL, 2009, p. I63). Bramall (2009, p. 268-269) mostra que alguns centros da Terceira Frente nas províncias ocidentais e no interior montanhoso das províncias costeira e central, como Tianshui e Panzhihua, obtiveram um crescimento impressionante e aumentaram sua produção industrial no final do período maoista. No entanto, eram projetos muito modestos para uma economia predominantemente agrária, com mais de $70 \%$ da força de trabalho ocupada no setor primário à época (BRAMALL, 2009, p. 272). O gráfico 4 mostra a distribuição de pessoal empregado em áreas urbanas e rurais entre 1952 e 20I6, e o gráfico 5, a distribuição nos três setores de atividade econômica. O número de pessoas empregadas nas áreas urbanas só começa a passar o das áreas rurais a partir de 2014 (NBS, 20I7a). Portanto, é problemático que alguns críticos generalizem a remuneração e as condições dos trabalhadores urbanos como norma para a população empregada antes da reforma de mercado.

\section{Gráfico 4. Distribuição dos empregados por área, rural ou urbana - China, 1952-2016 (em milhões)}

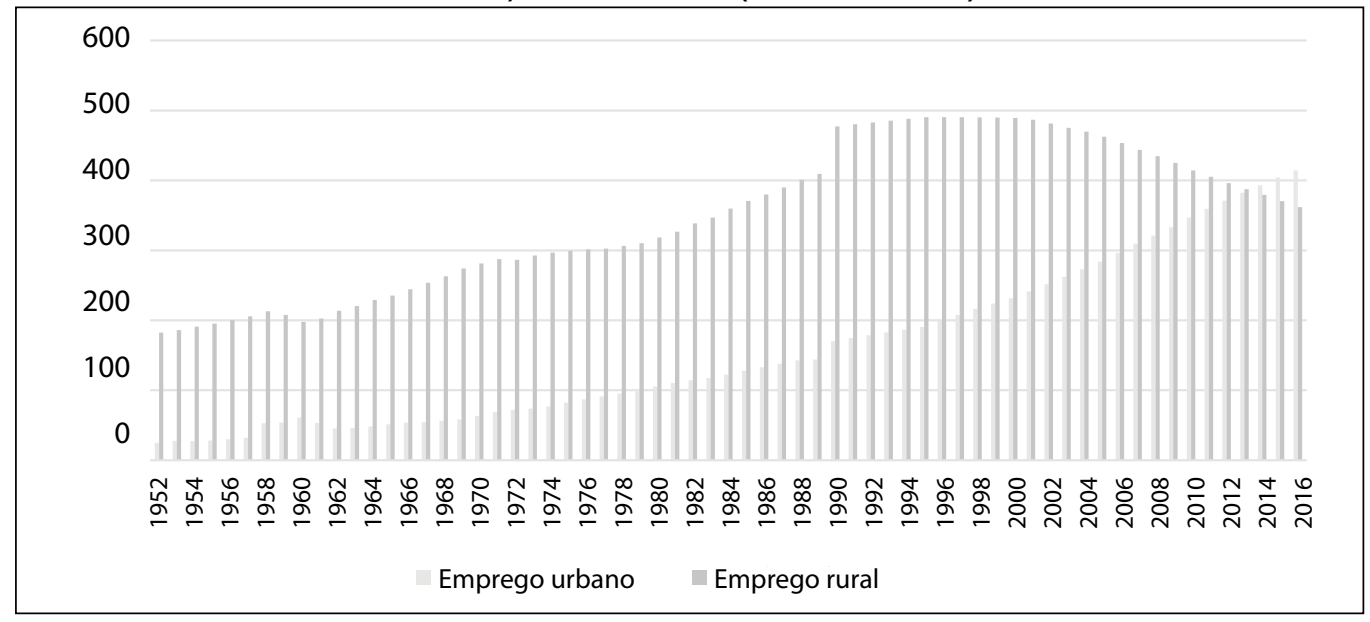

Fonte: China labor statistical yearbook 2017. 


\section{Gráfico 5. Distribuição dos empregados, por setor de atividade - China, 1952-2016 (em milhões)}

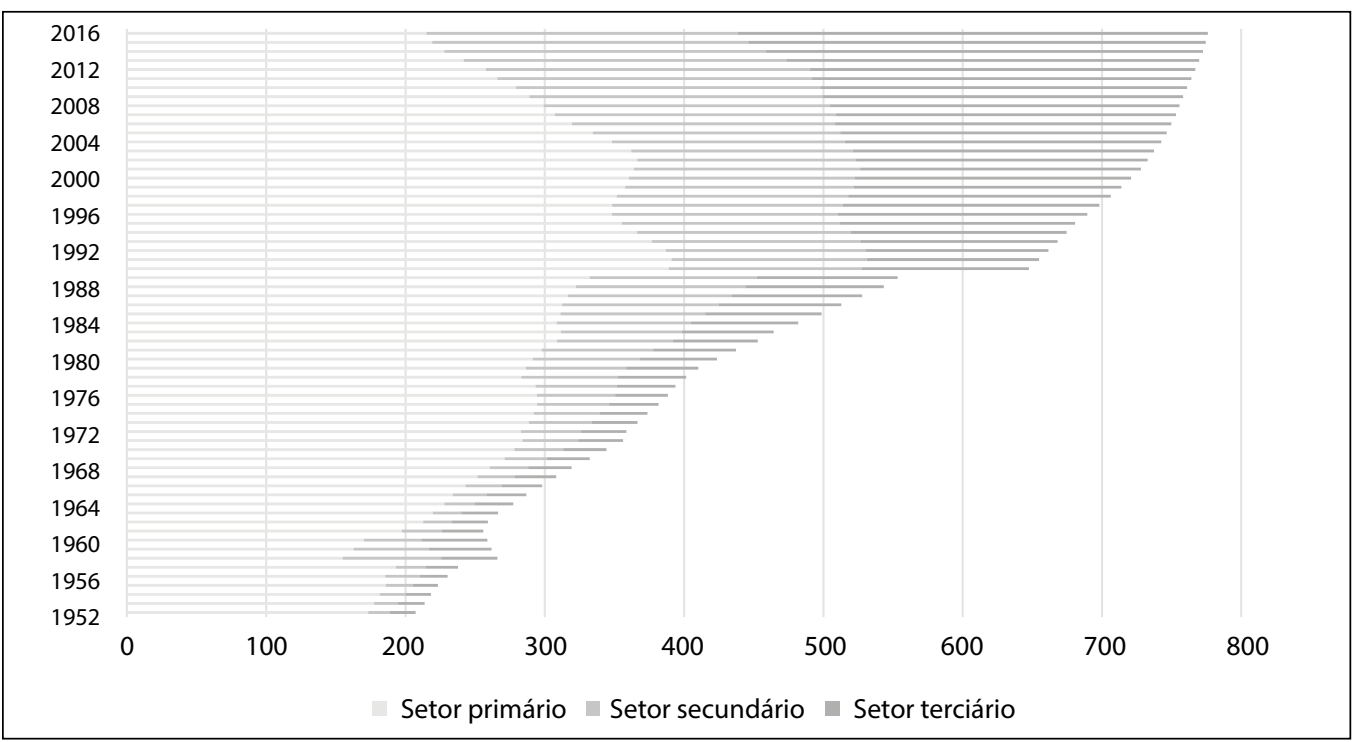

Fonte: China labor statistical yearbook 2017.

Houve um longo período de restrição de salários e de arrocho do consumo durante o período maoista, e o sistema de registro de residências foi firmemente aplicado para controlar o crescimento da força de trabalho urbana. Um estudo de Qi Hao sobre o sistema de incentivos (QI, 20I8, p. 4I3) mostrou que entre 1952 e 1978 o salário real médio dos trabalhadores no setor urbano permaneceu praticamente o mesmo durante o período. Para reduzir a pressão da crescente população urbana, já em I960 o governo iniciou o programa Xiafang (transferência de estudantes da escola secundária e da universidade, assim como de quadros industriais e técnicos, para o campo), com a esperança de aumentar a produção agrícola e promover a construção da Terceira Frente (BRAMALL, 2009, p. I63). Quando o programa terminou, em I977-I979, cerca de I8 milhões de pessoas diziam ter passado pelo shangshan xiaxiang (BRAMALL, 2009, p. I64).

Muitos projetos de construção foram implementados com mão de obra camponesa recrutada para cada empreendimento. Somada à força de trabalho xiafang, ela formava um grande contingente de trabalho de facto casual para a construção de infraestrutura. Segundo dados de Nickum citados por Bramall (2009, p. 224), de 40 a 60 milhões de camponeses estiveram envolvidos na acumulação de trabalho em meados dos anos I960, estimativa que aumenta para I20 a I40 milhões em I976-I977, quando o programa se intensificou e concentrou-se cada vez mais na formação de uma superbrigada e em projetos comunitários de conservação de água. Em média, um camponês se envolvia na acumulação de trabalho durante 30 dias por ano. A acumulação de trabalho é o processo de utilização de trabalho durante o inverno para a criação de capital fixo em terras expandidas, e em contrapartida o trabalhador recebia pontos de trabalho ou dedução do trabalho obrigatório, tal qual uma corveia (yiwu gong) 
(NICKUM, 1978, p. 273, 275). Como Bramall (2009, p. 242) calculou, a motivação política e ideológica adicional teve um efeito limitado para aumentar a produtividade do trabalho, já que muitos camponeses se desiludiram em meados dos anos I960. Ademais, a prioridade da industrialização sobre a agricultura levou a uma falta de investimento em recursos modernos para a agricultura. A estrutura de preços, desenhada para garantir um fornecimento barato de alimentos para os trabalhadores urbanos e matéria-prima agrícola para o setor industrial, também aumentou os incentivos para elevar a produtividade (BRAMALL, 2009, p. 247).

Esse é o pano de fundo do regime trabalhista antes das reformas de mercado em I978. O excedente de trabalhadores e camponeses foi transferido para que o Estado conduzisse políticas industriais, mas a acumulação por meios internos ainda não era suficiente para suprir a demanda. De acordo com matéria do Diário do Povo citada por Kornai (I992, p. 490), mais de $25 \%$ das estatais tiveram perdas todos os anos, e mais de 40 bilhões de yuans, o equivalente a metade do lucro da indústria chinesa, foram gastos nessas estatais para mantê-las. Como mostra o gráfico 6, os subsídios governamentais para empresas deficitárias ultrapassaram a renda gerada por impostos das estatais em 1989 (NBS, 2003). Com fundos externos limitados e falta de investimento no campo, as perdas do setor estatal só aumentavam o fardo da acumulação para os trabalhadores urbanos e rurais. Diversificar investimentos se tornou importante não apenas para a estabilidade econômica, mas também política. Abrir o país para o investimento estrangeiro aliviou a situação, sendo que este representava, em I995, I3\% do total de fundos reais para investimentos em ativos fixos (excluindo os lares rurais). Contudo, a porcentagem de investimento estrangeiro decaiu fortemente em um breve espaço de tempo, para 5,8\% em 2000 e menos de 0,37\% em 2016 (NBS, 20I7a).

\section{Gráfico 6. Imposto de renda arrecadado de empresas estatais e subsídios para empresas deficitárias — China, 1989-2000 (em 100 milhões de yuans)}

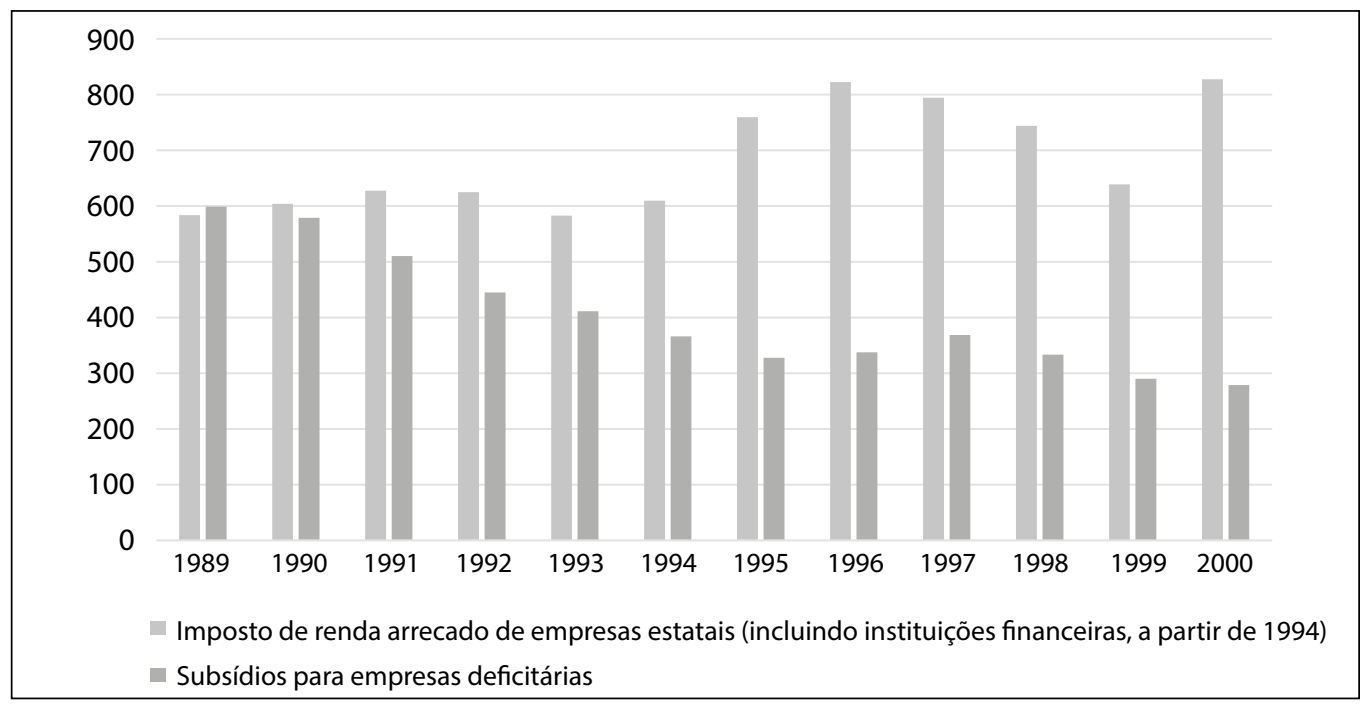

Fonte: China statistical yearbook 2013 (NBS 2003). 


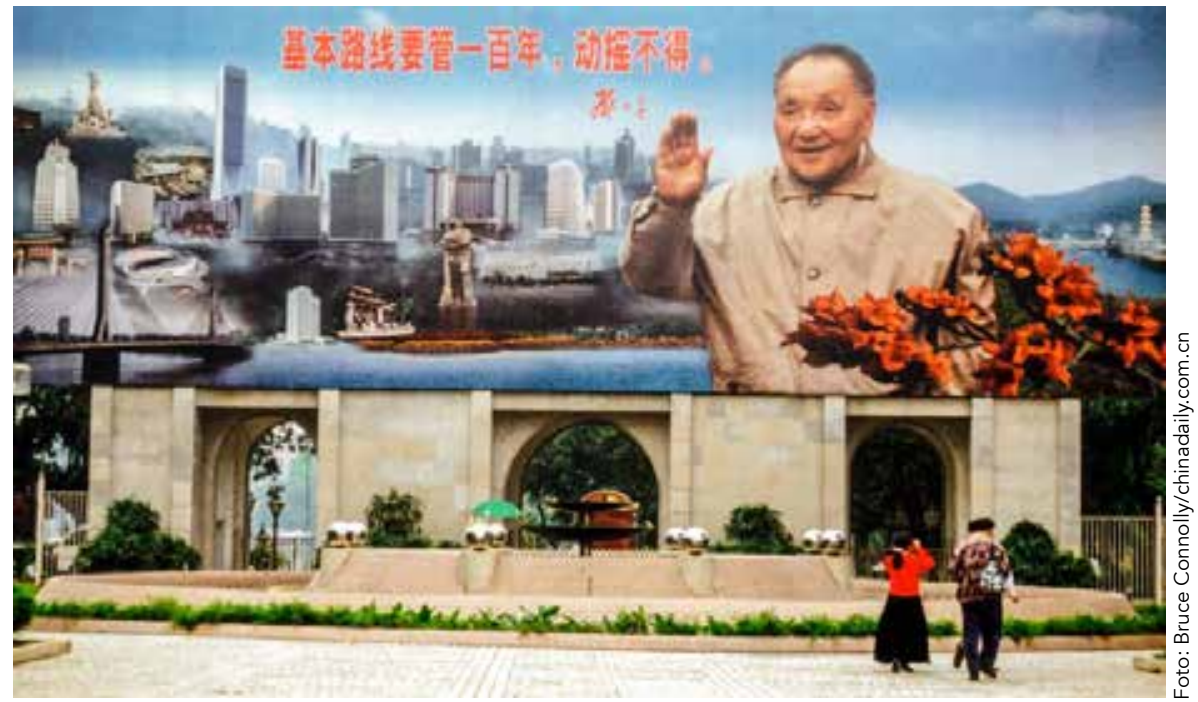

Cartaz de Deng Xiaoping na cidade de Guangzhou. O ex-presidente chinês é considerado o "pai" da modernização chinesa na economia

\subsection{Gargalo da acumulação primitiva socialista por meio da transfe- rência de excedentes agrícolas}

O aumento da produtividade industrial não foi suficiente. Como aponta Bramall (2009, p. 273), os níveis absolutos de produtividade estavam bem abaixo dos níveis mundiais; mais importante, contudo, é que o setor industrial era exíguo demais para sustentar as ambições políticas e econômicas da China, e, assim, o setor industrial do país era ineficiente em um sentido macroeconômico mais amplo. Aumentar o tamanho do setor industrial, no entanto, iria causar maior pressão sobre o setor rural, já sobrecarregado havia anos. A China também estava sob pressão adicional por conta de um bloqueio internacional e precisava garantir sua autossuficiência. É por isso que Chun (2006, p. 64) observou que era muito mais difícil para a China se modernizar em comparação com o desenvolvimento dependente das periferias capitalistas: os contrastes entre a estrutura de acumulação socialista e o Estado desenvolvimentista capitalista são muitos e se mostram na China contra o pano de fundo de maiores adversidades enfrentadas pela acumulação socialista em um mundo dominado por instituições políticas, econômicas, financeiras, militares e culturais capitalistas (LIN, 2006, p. 68).

Como muitos países subdesenvolvidos, que dependem de bens de produção e maquinário estrangeiro para renovar e atualizar seus equipamentos industriais e sua capacidade técnica, a China enfrentou os mesmos problemas. No final da era Mao, o potencial técnico das indústrias introduzidas pela União Soviética ${ }^{6}$ nos anos 1950 havia se exaurido. Gargalos no crescimento da produtividade exigiam a introdução de equipamentos e técnicas avançados. Deng Xiaoping é com frequência visto como destruidor da autarquia e inventor no comércio exterior, mas isso sempre existiu du-

\footnotetext{
A assistência financeira e técnica soviética à China durante os anos 1950 e 1960, simbolizada por 156 projetos-chave que incluíam 25 novas minas de carvão, 25 novas usinas de energia e 24 novas fábricas de maquinário, foi considerada uma das maiores transferências de tecnologia da história (BRAMALL, 2009, p. 100)
} 
rante o período maoista (gráfico 7). Por exemplo, segundo Bramall (2009, p. 362), já em 1965 a China importava mais valor em bens do Japão e da Europa Ocidental que da URSS. Para o autor, a mudança mais significativa em termos de política econômica no início dos anos 1970 foi a crescente dependência da importação de bens de produção modernos do Japão e do Ocidente. A visita de Nixon, em 1972, levou a um descongelamento gradual das relações internacionais e a aumentos significativos nas importações (BRAMALL, 2009, p. I66).

\section{Gráfico 7. Valor total das importações e exportações chinesas, 1950-1980 (em US\$ 100 millhões)}

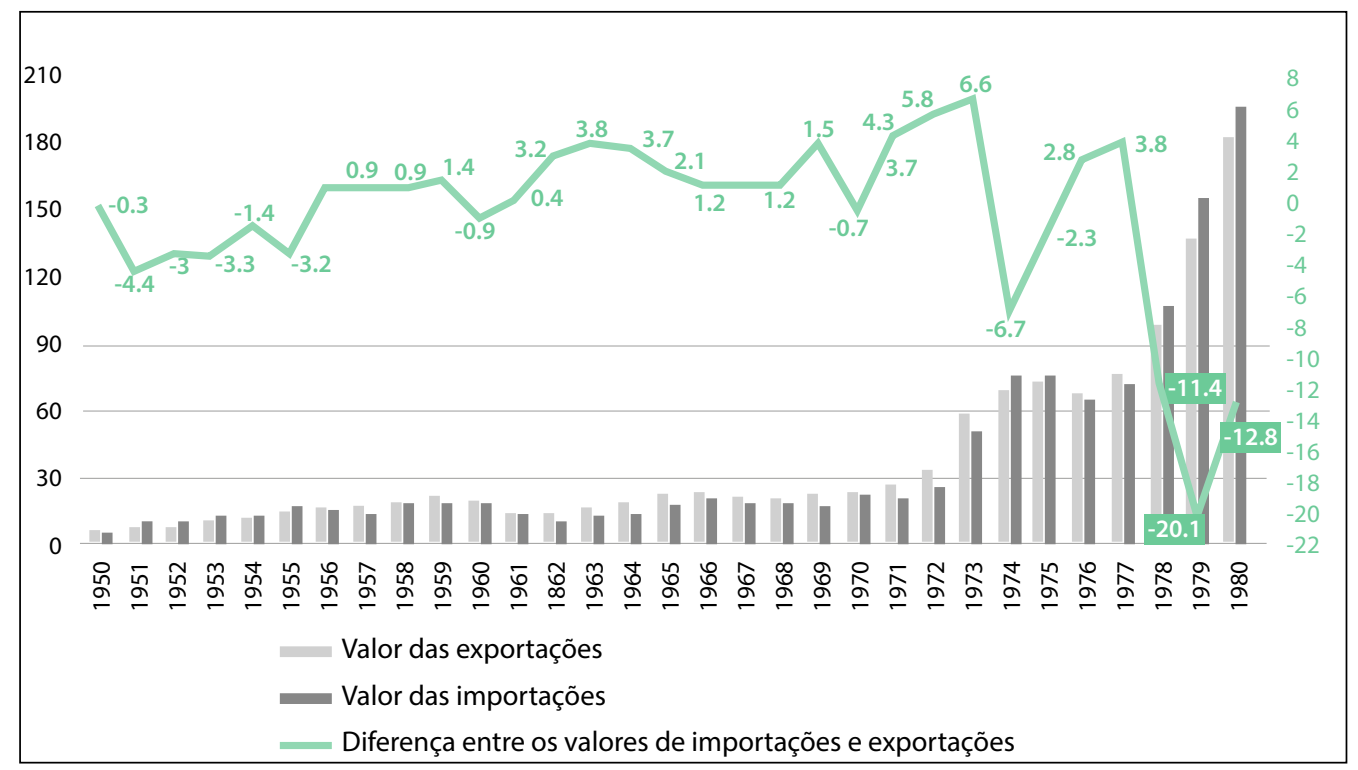

Fonte: China statistical yearbook 1981.

Depois que a China e os Estados Unidos restauraram formalmente suas relações diplomáticas, em $\mathrm{I}^{\mathrm{o}}$ de janeiro de $\mathrm{I} 979$, os chineses aceleraram suas importações, que iam de armas, aeronaves, usinas siderúrgicas, petroquímicos, equipamento de mineração e plataformas de petróleo até trigo (CHENG, 1979). Os compromissos de importação cresceram dez vezes em relação ao ano anterior e mudaram rapidamente transformaram o superávit comercial chinês em déficit. A conta total de importações, incluindo as que estavam em negociação, chegou a cerca de U\$ 60 bilhões em 1978, enquanto as reservas cambiais atingiam apenas entre US\$ 2 bilhões e US\$ 4 bilhões (CHENG, 1979). O gráfico 7 mostra a queda acentuada na balança comercial, de um superávit de US\$380 milhões em I977 para um déficit de US\$ I,I bilhão em I978, que aumentou para US\$ 2 bilhões no ano seguinte. A importação de bens estrangeiros pode ter temporariamente aliviado a pressão nos gargalos industriais, mas aumentou a dependência de matérias-primas e empréstimos estrangeiros de longo prazo. O comércio por si só não criaria as bases industriais domésticas. 


\subsection{A reforma das indústrias estatais}

Como mostrado no gráfico 6, a contribuição tributária das estatais só começou a exceder os subsídios após I990. Essa reviravolta veio depois de uma série de reformas introduzidas nos anos 1990.

A reforma das estatais busca "agarrar o grande e abrir mão do pequeno" (zhua da fang xiao), em vez de realizar uma privatização total. Embora a maioria das estatais de pequeno e médio porte tenha sido privatizada, I20 grandes grupos empresariais nas indústrias de capital intensivo, consideradas de importância estratégica, foram selecionados pelo Conselho de Estado nos anos 1990 para criar um "time nacional" apoiado por políticas preferenciais. Nolan (200I) agrupou essas políticas em três categorias:

I) Proteção tarifária e não tarifária. O nível médio das tarifas era de quase $25 \% \mathrm{em}$ I999; sobre importação de veículos, entre 80\% e I00\%; sobre produtos agrícolas, $31 \%$. A proteção não tarifária incluía transferência compulsória de tecnologia referente a certos bens importados. O governo combinava fornecedores domésticos de peças com investidores estrangeiros, excluía rotineiramente firmas estrangeiras dos canais domésticos de distribuição e exigia de investidores estrangeiros que estabelecessem investimentos conjuntos com parceiros domésticos selecionados (NOLAN, 200I, p. I8).

2) Uma lei empresarial de 1994 permitiu que empresas industriais chave do Estado se tornassem entidades legais independentes, formalmente separadas do governo, e adotassem estruturas acionárias. As estatais puderam reter os lucros e tomar decisões sobre comércio internacional. Ganharam o direito de criar veículos financeiros internos e de gerenciar companhias no âmbito de um mesmo grupo estatal. Muitos centros estatais de pesquisa e desenvolvimento foram transferidos para elas. As estatais-chave lideraram a formação de um mercado financeiro doméstico e, mais tarde, de companhias chinesas nos mercados internacionais. No entanto, era um processo firmemente controlado, no qual o Estado ainda mantinha ações majoritárias e, em vez de ser um movimento na direção das privatizações, como alguns anteciparam, tornou-se um mecanismo-chave para que as estatais absorvessem capital privado (NOLAN, 200I, p. I9).

3) Apoio financeiro estatal direto: os quatro grandes bancos estatais fizeram um esforço concentrado para apoiar o time nacional. Um procedimento de empréstimo simplificado foi estabelecido no final dos anos 1990 e foram abertas centenas de agências bancárias dedicadas a aconselhar as 120 maiores estatais e facilitar o acesso ao mercado de capitais. Bilhões em empréstimos foram concedidos para facilitar a expansão e exportação de setores-chave (NOLAN, 200I, p. I9).

Apesar de tendências conflitantes, incluindo viradas na direção de privatizações generalizadas, o resultado das reformas das estatais foi transformador. Em 2006, o primeiro-ministro Wen Jibao relatou ao II $^{\circ}$ Congresso Nacional do Povo que, em 


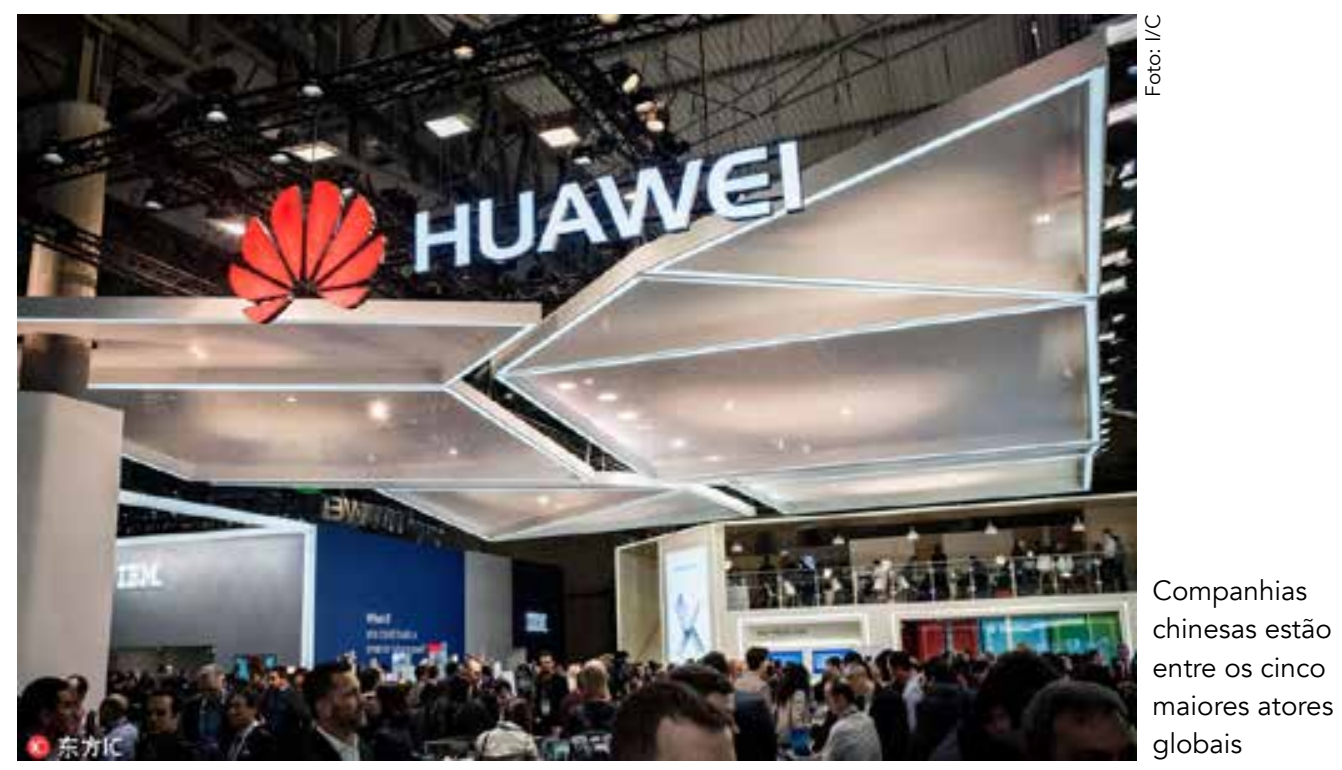

comparação com 2002, os lucros totais cresceram 223\%, e a contribuição tributária, I05\% (PREMIER..., 2008). Segundo um relatório do Ministério do Comércio, apenas as estatais não financeiras contribuíram com $34 \%$ da renda fiscal do Estado em 2013 (MOFCOM, 20I4). Se as estatais financeiras pagarem o mesmo valor em impostos que as estatais não financeiras, juntas elas responderiam por $68 \%$ da renda fiscal do Estado (CHINA DAILY, 20I5).

Os resultados da reforma das estatais não foram os que Nolan esperava. Enquanto reconhece o esforço feito pelo governo chinês para criar "campeões nacionais", ele era bastante cético quanto ao futuro deles, já que a competição global em indústrias de capital intensivo era extrema.

Segundo um relatório do Bolton Consulting Group citado por Poon (20I4), pesquisador da ONU, companhias chinesas estão entre os cinco maiores atores globais, em seis dos sete grandes ramos industriais de equipamentos (energia fotovoltaica, telecomunicações sem fio, energia eólica, energia via carvão, transmissão de energia, material ferroviário e aviação civil). As estatais chinesas se tornaram competitivas ante as corporações privadas em áreas antes vistas como fortalezas das empresas de capital estrangeiro, tais como reconhecimento de marcas, recursos de marketing e vendas e qualidade de produto (DAVIES, 20I3, p. 30), e avançaram para os principais mercados de produtos de países desenvolvidos - por exemplo, equipamento pesado, como máquinas de construção, e outros setores de equipamentos - , roubando uma fatia do mercado das companhias ocidentais em mercados não pertencentes à OCDE (POON, 20I4, p. 4). Como Lo (20I6b) argumenta, um desvio notável da tendência aconteceu em 2008, quando, em vez de praticar austeridade, como todas 


\section{A lei da acumulação primitiva \\ socialista pode ser um modelo \\ explanatório útil: se a indústria \\ estatal está se desenvolvendo e \\ consolidando em oposição à lei \\ do valor, isso só pode ocorrer \\ porque alguma outra lei está \\ se contrapondo à lei do valor, \\ modificando-a, desviando-a ou \\ mesmo suprimindo-a parcialmente}

as outras grandes economias, a China aumentou maciçamente o investimento produtivo por intermédio de seus bancos estatais e se apoiou nas estatais para sustentar o crescimento econômico. Barry Naughton, que segue de perto as reformas de mercado chinesas e uma vez afirmou que a planificação estatal estava sendo eliminada pelo livre mercado (NAUGHTON, I995), mudou de ideia. Ele observou que o tamanho da força de trabalho das estatais em relação à força de trabalho total não reflete diretamente seu peso na economia, já que o controle e a propriedade do Estado estão concentrados em setores de capital intensivo e de capital humano intensivo; embora a participação das estatais no total de ativos produtivos seja relativamente pequena, é substancial em setores estrategicamente importantes ou monopolistas (terra, recursos naturais, transporte, comunicação, intermediários e equipamentos de produção) (NAUGHTON, 20I7). Em outras palavras, apesar das vicissitudes das reformas, as estatais ainda estão no alto comando da economia.

\section{ACUMULAÇ̃̃O PRIMITIVA SOCIALISTA COMO MODELO EXPLANATÓRIO}

Como descrito, em contraste com a maior parte dos "Estados desenvolvimentistas", nos quais a intervenção estatal criou grandes empresas privadas monopolistas, que dominam a economia, o alto comando da economia chinesa sempre foi guiado pelo setor estatal e os maiores bancos ainda são estatais; a emergência fenomenal de um setor privado dinâmico após 1979 não só não excluiu o Estado da economia, ao contrário do que alguns esperavam, como a persistente configuração institucional garante que boa porção de seus excedentes seja absorvida pelo setor estatal. Este artigo, portanto, argumenta que_a lei da acumulação primitiva socialista pode ser um modelo explanatório útil: se a indústria estatal está se desenvolvendo e consolidando em oposição à lei do valor, isso só pode ocorrer porque alguma outra lei está se contra- 
pondo à lei do valor, modificando-a, desviando-a ou mesmo suprimindo-a parcialmente (PREOBRAZHENSKY, I965, p. I39).

O economista soviético Preobrazhensky (1965) chamou essa "outra lei" de lei da acumulação primitiva socialista (LoPSA, sigla em inglês). Diz-se que a transição para o socialismo será irreversível quando essa lei suplantar a lei do valor em escala global. Até lá, a economia soviética ainda seria uma economia de transição na qual elementos do capitalismo e do que poderia se tornar socialismo competiriam pela supremacia. Para Preobrazhensky, a acumulação capitalista já se tornara o modo de produção dominante sob a sociedade feudal antes da promulgação revolucionária do seu domínio; ao passo que em um país no qual o capitalismo era subdesenvolvido quando o proletariado tomou o poder, como a Rússia, as bases materiais do socialismo precisavam ser acumuladas como projeto político consciente, com regras estabelecidas contra o setor privado doméstico e internacional - daí a LoPSA. Preobrazhensky levantou essa ideia quando a Nova Política Econômica (NEP, sigla em inglês) reviveu a acumulação capitalista na cidade e no campo, levando a debates ferozes a respeito da direção das políticas econômicas. Richard Day observa que, segundo Marx, a acumulação primitiva capitalista dependeu da expropriação do camponês e da criação do trabalho "livre": "livre" no sentido de ter sido afastado do solo e transformado em uma commodity explorável no mercado de trabalho. Apenas então poderia o capital mercantil crescer e emergir como capital industrial. Raciocinando analogicamente, Preobrazhensky situou o empreendimento soviético nacionalizado em uma posição mais ou menos comparável à do capital mercantil para Marx. O comerciante havia sido cercado por elementos feudais, assim como as empresas nacionalizadas tinham sido deixadas à deriva em um mar de relações capitalistas sob a NEP. O comerciante havia acumulado o excedente social, transformando-o em capital industrial e universalizando o novo modo de produção até a extensão permitida pelas contradições inerentes ao sistema capitalista. De maneira similar, o empreendimento socialista acumularia o excedente social graças aos preços de monopólio com a diferença crítica de que o modo de produção socialista alcançaria a verdadeira universalidade ao superar a contradição entre cidade e campo (DAY, I975, p. 218).

Preobrazhensky mostrou que a expansão da produção socializada e planificada na União Soviética exigia a absorção de recursos externos à economia estatal - da pequena produção doméstica, comércio interno e internacional e influxo de investimento estrangeiro. O Estado planejaria conscientemente a expansão das indústrias estatais. Capitalistas poderiam operar na economia (com certas restrições) ou formariam empresas conjuntas com o Estado, que funcionariam sob o plano geral e estariam 
sujeitas ao sistema financeiro estatal. A contradição fundamental entre capitalistas destituídos de poder e um Estado proletário a que eles estariam forçados a servir seria a fonte de todos os grandes conflitos nessa sociedade de transição.

A força motriz da produção capitalista é a busca pelo lucro e seu regulador é a lei do valor. O capitalismo satisfaz as necessidades do consumidor graças a esse mecanismo. Em particular, o trabalhador recebe sua parte de um fundo de meios de consumo ao vender sua força de trabalho. De que maneira a economia estatal é diferente do capitalismo, nesse ponto? Por um lado, ela já deixou de ser produção que visa ao lucro, à mais-valia. Por outro lado, ela ainda não é produção voltada ao consumo dos trabalhadores da economia estatal e ainda menos das pessoas da economia privada. O equilíbrio dinâmico da economia estatal pode ser destruído se a proporção necessária de reprodução ampliada ditada pela situação econômica como um todo não for garantida por uma adequada e constante taxa de crescimento de acumulação do produto excedente em forma material, e isso sempre significa restrição da demanda individual. A contradição entre essas duas tendências no âmbito da economia estatal não toma a forma de antagonismo de classes, mas ainda assim existe. Essa contradição também caracteriza plenamente a lei da acumulação primitiva socialista em si, no que tange à distribuição. Por um lado, a reprodução ampliada no setor socialista significa reprodução automática e quantitativamente ascendente das relações de produção socialistas, assim como das proporções anuais correspondentes na distribuição das forças produtivas. Mas, por outro lado, essa expansão quantitativa das relações socialistas, como exige alienação de uma certa quantidade de produto excedente da economia estatal e subordina os aumentos salariais à função de acumulação, limita o crescimento da qualidade das relações socialistas e mantém a diferença entre o nível de salário e o valor da força de trabalho (PREOBRAZHENSKY, I965, p. 72-73).

Essas contradições se aplicam à China de hoje. A reforma de mercado mostrou como a China absorve capital e tecnologia privados para expandir sua capacidade industrial. O setor privado está agora cada vez mais em conflito com o setor estatal dominante. Estatais também foram transformadas para se integrarem ao mercado capitalista mundial, e, portanto, aumenta a subjugação delas à lei do valor. A financeirização completa dos ativos estatais está agora sendo discutida pelo Estado como próximo passo para a integração total com a economia mundial. No entanto, a produção com fins lucrativos ainda não é a força motriz dominante no setor estatal, já que vem sendo usada para implementar objetivos políticos e sociais ambiciosos do Estado, como a erradicação da pobreza absoluta e a construção de uma rede ferroviária nacional de alta velocidade. Isso existe em paralelo com poderosas facções que advogam pela retirada total do poder público das empresas estatais.

$\mathrm{O}$ aumento de produtividade na indústria estatal e a conexão desta com o mercado mundial resultaram em relações de comércio mais profundas e integradas, além de produzirem mais contradições entre os dois sistemas de acumulação. Como isso vai acabar, permanece uma questão em aberto. A economia de transição entre o 
capitalismo e o socialismo não pode existir para sempre em um país imerso no mercado capitalista mundial. A diferença mais notável entre a União Soviética do tempo de Preobrazhensky e a China de hoje é que a primeira planejou e declarou a extensão do domínio dos trabalhadores pelo mundo todo, enquanto a segunda insiste em ser uma leal defensora do sistema mundial vigente.

* Doutoranda (PhD student) em Estudos de Desenvolvimento na Escola de Estudos Orientais e Africanos (SOAS), Universidade de Londres, Reino Unido. Sua pesquisa se concentra na economia política do desenvolvimento econômico da China e no impacto do comércio exterior e do investimento da China sobre os países em desenvolvimento.

Agradecimentos: a autora deseja agradecer ao painel editorial da Review of Radical Political Economics por seus comentários e sugestões a respeito das primeiras duas versões deste artigo. A autora fez revisões substanciais no manuscrito com base nesses comentários e em críticas construtivas. A autora também deseja agradecer Dic Lo e Heiko Khoo por seus úteis comentários.

Declaração de conflito de interesses: a autora declara não haver nenhum potencial conflito de interesses no que diz respeito à pesquisa, autoria ou publicação deste artigo.

Apoio: a autora não recebeu nenhum apoio financeiro para a pesquisa, autoria ou publicação deste artigo.

O artigo original em inglês foi publicado no vol. 52, $n^{\circ} 4$, da Review of Radical Political Economics (EUA), em maio de 2020. Tradução de Isadora Sinay.

Texto recebido em 25 de março de 2021; aprovado em 29 de março de 2021. 
ANDREAS, Joel. Changing colours in China. New Left Review, n. 54, p. 123-42, 2008.

BOFIT. More Chinese companies make fortune global 500 list. Bank of Finland Institute for Economies in Transition Weekly, July 27, 2018. Disponível em: <www.bofit.fi/en/monitoring/weekly/2018/ vw201830_6>.

BRAMALL, Chris. Chinese Economic Development. New York: Routledge, 2009.

CARCHEDI, Guglielmo; ROBERTS, Michael. The long roots of the present crisis: Keynesians, austerians, and Marx's law. In: ROBERTS, Michael; CARCHEDI, Guglielmo (Ed.). World in crisis: a global analysis of Marx's law of profitability. Chicago: Haymarket Books, 2018. p. 13-35.

CENDROWSKI, Scott. China's 12 biggest companies are all government owned. Fortune, July 22, 2015. Disponível em: <http://fortune.com/2015/07/22/china-global-500-government-owned>.

CHENG, Hang-Sheng. Great leap outward? Federal Reserve Bank of San Francisco Weekly Letter, January 5, 1979. Disponível em: <www.frbsf.org/economic-research/files/el79-01.pdf>.

CHINA DAILY. 国家税收半数来自国企引热议 专家:打造企业公平竞争环境 [Half of national tax revenue comes from state-owned enterprises]. 财经一人民网, January 6, 2015. Disponível em: <http://finance. people.com.cn/n/2015/0106/c1004-26331984.html>.

CIC. China investment corporation annual report. Beijing: China Investment Corporation, 2012.

China investment corporation annual report. Beijing: China Investment Corporation, 2015.

DAVIES, Ken. China investment policy: an update. OECD Working Papers on International Investment. Paris: Organization for Economic Co-Operation and Development, 2013. Disponível em: <www. oecd-ilibrary.org/content/workingpaper/5k46911hmvbt-en>.

DAY, Richard B. Preobrazhensky and the theory of the transition period. Soviet Studies, v. 27, n. 2, p. 196-219, 1975.

EATON, Sarah. The advance of the State in contemporary China: State-market relations in the reform era. Cambridge: Cambridge University Press, 2015.

HART-LANDSBERG, Martin; BURKETT, Paul. China and socialism: market reforms and class struggle. New York: Monthly Review Press, 2005.

HARVEY, David. The "new" imperialism: accumulation by dispossession. Socialist Register, v. 40, n. 40, 2004. Disponível em: <http://socialistregister.com/index.php/srv/article/view/5811>.

A brief history of neoliberalism. Oxford: Oxford University Press, 2007.

HE, Laura; ZHANG, Shidong. Is Chinese capitalism in crisis, as stock market rout drives private companies into the state's arms?. South China Morning Post, October 20, 2018. Disponível em: <www. scmp.com/business/companies/article/2169381/chinese-capitalism-crisis-stock-market-rout-drivesprivate>. Cheng 21

HEILMANN, Sebastian; MELTON, Oliver. The reinvention of development planning in China (19932012). Modern China, v. 39, n. 6, p. 580, 2013.

HORNBY, Lucy. China rows back on state-sector reforms. Financial Times, June 14, 2016. Disponível em: <www.ft.com/cms/s/0/92e52600-31f7-11e6-ad39-3fee5ffe5b5b.html\#axzz4GZJhy5Yg>.

ILO. Labour productivity: ILO modelled estimates. International Labour Organization Estimates and Projections Series, May, 2018a. Disponível em: <www.ilo.org/ilostat/faces/oracle/webcenter/ portalapp/pagehierarchy/Page3.jspx?MBI_ID=49\&_adf.ctrl-state=1eiOenc00_95\&_afr-Loop=1318305438837637\&_afrWindowMode=0\&_afrWindowld=1eiOenc00_92\#!>. 
Global wage report 2018/19: what lies behind gender pay gaps. Geneva: International Labour Organization, 2018b. Disponível em: <www.ilo.org/global/publications/books/WCMS_650553/ lang-en/index.htm>.

JESSOP, Bob. The "return" of the national state in the current crisis of the world market. Capital \& Class, v. 34, n. 1, p. 38-43, 2010.

KHOO, Heiko. Is China still socialist?: a Marxist critique of János Kornai's analysis of China. London: King's College London, 2018.

KORNAI, János. The socialist system: the political economy of communism. Princeton: Princeton University Press, 1992.

LI, Jing. China's new labor contract law and protection of workers. Fordham International Law Journal, v. 32, n. 3, 2008. Disponível em: <http://ir.lawnet.fordham.edu/cgi/viewcontent.cgi?article $=2154 \&$ context $=i l j>$.

LIN, Chun. The transformation of Chinese socialism. Durham: Duke University Press, 2006.

LIN, Kevin. Recomposing Chinese migrant and state-sector workers. In: Chinese workers in comparative perspective, ed. Anita Chan, 69-84. Ithaca: Cornell University Press, 2015.

LO, Dic. Alternatives to neoliberal globalization: studies in the political economy of institutions and late development. New York: Palgrave Macmillan, 2012.

China confronts the great recession: "Rebalancing" neoliberalism, or else? In: Emerging economies during and after the Great Recession, eds. Philip Arestis and Malcolm Sawyer, 232-69. London: Palgrave Macmillan, 2016 a.

Developing or under-developing? Implications of China's "going out" for late development. SOAS Department of Economics Working Paper, no. 198. London: School of Oriental and African Studies, 2016b. Disponível em: <www.soas.ac.uk/economics/research/workingpapers/file113670. $\mathrm{pdf}>$.

; YU, Zhang. Making sense of China's economic transformation. Review of Radical Political Economics, v. 43, n. 1, p. 33-55, 2011.

LOCKETT, Hudson. China plans Rmb4.7tn in infrastructure funding. Financial Times, May 11, 2016. Disponível em: < https://www.ft.com/content/ec3df7f3-1254-3da6-8ee9-e2434391bf15>.

LUTHJE, Boy. Exporting corporatism?: German and Japanese transnationals' regimes of production in China. In: CHAN, Anita (Ed.). Chinese workers in comparative perspective. Ithaca: Cornell University Press, 2015. p. 21-43.

MCNALLY, Christopher A. Sino-capitalism: China's reemergence and the international political economy. World Politics, v. 64, n. 4, p. 741-776, 2012.

MOFCOM. 2013年全国国有企业财务决算情况 [Financial statements of state-owned enterprises in China in 2013]. July 28, 2014. Disponível em: <www.mof.gov.cn/preview/qiyesi/zhengwuxinxi/gongzuodongtai/201407/t20140728_1118640.html.

2014年度中国对外直接投资统计公报 [2014 statistical bulletin of China's outward direct investment statistical report]. September 17, 2015. Disponível em: <http://fec.mofcom.gov.cn/article/tjsj/ tjgb/201512/20151201223579.shtml.

NAUGHTON, Barry. The third front: defense industrialization in the Chinese interior. The China Quarterly, n. 115, p. 351-86, 1988.

Growing out of the plan: Chinese economic reform (1978-1993). New York: Cambridge University Press, 1995. 
NBS. 中国统计年鉴 2003 [China statistical yearbook 2003]. National Bureau of Statistics of the People's Republic of China, 2003. Disponível em: <http://tongji.oversea.cnki.net.ezproxy.soas.ac.uk/chn/ navi/YearBook.aspx?id=N2006010337\&floor=1\#\#\#>.

Statistical communiqué of the People's Republic of China on the 2015 national economic and social development. National Bureau of Statistics of China, 2016a. Disponível em: <www.stats. gov.cn/ english/PressRelease/201602/t20160229_1324019.html>.

2015年农民工监测调查报告 [Monitoring report of migrant workers 2015]. National Bureau of Statistics of the People's Republic of China, 2016b. Disponivel em: <www.stats.gov.cn/tjsj/ zxfb/201604/t20160428_1349713.html>.

China labor statistical yearbook 2017 [中国劳动统计年鉴]. National Bureau of Statistics of the People's Republic of China, 2017a. Disponível em: <http://tongji.oversea.cnki.net.ezproxy.soas. ac.uk/chn/navi/HomePage. aspx?id=N2018070151\&name $=$ YZLDT\&floor=1>.0

中国人口和就业统计年鉴 2017 [China population and employment statistics yearbook 2017]. National Bureau of Statistics of the People's Republic of China, 2017b. Disponivel em: <http://tongji. oversea.cnki.net.ezproxy.soas.ac.uk/chn/navi/HomePage. aspx?id=N2017120250\&name=YZGRL\&fl oor $=1>$.

中国统计年鉴 2018 [China statistical yearbook 2018]. National Bureau of Statistics of the People's Republic of China, 2018. Disponível em: <www.stats.gov.cn/tjsj/ndsj/2018/indexeh.htm.

NDRC et al. 境外投资产业指导政策 [Policy guidance for overseas investment]. July 5, 2006. Disponível em: <http://tradeinservices.mofcom.gov.cn/article/ zhengce/hyfg/201710/447.html>.

NICKUM, James E. Labour accumulation in rural China and its role since the Cultural Revolution. Cambridge Journal of Economics, v. 2, n. 3, p. 273-86, 1978.

NOLAN, Peter. China and the global economy: national champions, industrial policy and the big business revolution. New York: Palgrave, 2001.

PANITCH, Leo; GINDIN, Sam. The making of global capitalism: the political economy of American empire. London: Verso, 2012.

POON, Daniel. China's development trajectory: a strategic opening for industrial policy in the South. United Nations Conference on Trade and Development Discussion Paper, n. 218. Geneva: United Nations Conference on Trade and Development, 2014. Disponível em: <http://unctad.org/en/PublicationsLibrary/ osgdp20144_en.pdf>.

PREMIER says China's state sector robust. Beijing Review, March 5, 2008. Disponível em: <www. bjreview.com.cn/2008lianghui/txt/2008-03/05/content_102596.htm>.

PREOBRAZHENSKY, Eugene A. The new economics. Oxford: Clarendon Press, 1965.

PRINGLE, Tim. Labour as agent of change: the case of China. In: PRADELLA, Lucia; MAROIS, Thomas (Ed.). Polarizing development: alternatives to neoliberalism and the crisis. London: Pluto Press, 2014. p. 192-202.

Ql, Hao. "Distribution according to work": an historical analysis of the incentive system in China's state-owned sector. Review of Radical Political Economics, v. 50, n. 2, p. 409-426, 2018.

SALIDJANOVA, Nargiza. Going out: an overview of China's outward foreign direct investment. USCC Staff Research Report; US-China Economic and Security Review Commission, 2011. Disponível em: $<$ www.uscc.gov/sites/default/files/Research/GoingOut.pdf $>$.

SMITH, John. Imperialism in the twenty-first century: globalization, super-exploitation, and capitalism's final crisis. New York: Monthly Review Press, 2016. 
STILL kicking. The Economist, April 30, 2016. Disponível em: <www.economist.com/business/2016/04/30/still-kicking>.

TABETA, Shunsuke; CHO, Yusho. China's cash-strapped companies sell stakes to local governments. Nikkei Asian Review, November 1, 2018. Disponível em: <https://asia.nikkei.com/Economy/China-scash- strapped-companies-sell-stakes-to-local-governments $>$.

TEN BRINK, Tobias. Global political economy and the modern state system. Translation Jeff Bale. Leiden: Brill Academic Publishers, 2014.

UNGER, Jonathan. Chinese associations, civil society, and state corporatism: disputed terrain. In: p. 1-13

(Ed.). Associations and the Chinese State: contested spaces. New York: M.E. Sharpe, 2008.

; CHAN, Anita. China, corporatism, and the East Asian model. The Australian Journal of Chinese Affairs, n. 33, p. 29-53.

WILDAU, Gabriel. China's Xi Jinping revives Maoist call for "self-reliance." Financial Times, November 12, 2018. Disponível em: <www.ft.com/content/63430718-e3cb-11e8-a6e5-792428919cee>.

WOETZEL, Jonathan et. al. Bridging infrastructure gaps: has the world made progress? McKinsey Global Institute Discussion Paper, 2017. Disponível em: <www.mckinsey.com/industries/capital-projects-and-infrastructure/our-insights/ bridging-infrastructure-gaps-has-the-world-made-progress $>$.

WOLF, Martin. Consumption to replace investment as key to China growth. Financial Times, May 29, 2018. Disponível em: <www.ft.com/content/627ab75c-4256-11e8-97ce-ea0c2bf34a0b>.

WOOD, Ellen Meiksins. The empire of capital. London: Verso, 2005.

WORLD BANK. Exports of goods and services (\% of GDP). World Bank National Accounts Data; OECD National Accounts Data Files. 2016. Disponível em: <http://data.worldbank.org/indicator/ NE.EXP. GNFS.ZS/countries/1W-CN-4E?display=graph>.

$\mathrm{XU}$, Chenggang. Capitalism and socialism: a review of Kornai's dynamism, rivalry, and the surplus economy. Journal of Economic Literature, v. 55, n. 1, p. 19-208, 2017.

ZALAN, Eszter. Divided EU debates China market economy status. EUobserver, January 13, 2016. Disponível em: <https://euobserver.com/eu-china/131801>. 